Portland State University

PDXScholar

Business Faculty Publications and

Presentations

The School of Business

4-2018

\title{
Director Networks and Credit Ratings
}

Bradley W. Benson

Ball State University

Subramanian R. Iyer

University of New Mexico

Kristopher Kemper

Ball State University

Jing Zhao

Portland State University, jizhao@pdx.edu

Follow this and additional works at: https://pdxscholar.library.pdx.edu/busadmin_fac

Part of the Finance and Financial Management Commons

Let us know how access to this document benefits you.

\section{Citation Details}

Benson, B. W., Iyer, S. R., Kemper, K. J., \& Zhao, J. (2018). Director Networks and Credit Ratings. Financial Review, 53(2), 301-336.

This Post-Print is brought to you for free and open access. It has been accepted for inclusion in Business Faculty Publications and Presentations by an authorized administrator of PDXScholar. Please contact us if we can make this document more accessible: pdxscholar@pdx.edu. 


\title{
Director Networks and Credit Ratings ${ }^{\dagger}$
}

\author{
Bradley W Benson \\ Miller College of Business, Ball State University, \\ Muncie, IN 47306. bbenson@bsu.edu \\ Subramanian Rama Iyer* \\ FITE Department, Anderson School of Management \\ University of New Mexico, Albuquerque, NM 87131, \\ sriyer@unm.edu \\ Kristopher J Kemper \\ Miller College of Business, Ball State University, \\ Muncie, IN 47306. kjkemper@bsu.edu \\ Jing Zhao \\ School of Business Administration \\ Portland State University, Portland, OR 97207 \\ jingzhao@pdx.edu
}

\begin{abstract}
We explore the effect of director social capital, directors with large and influential networks, on credit ratings. Using a sample of 11,172 firm-year observations from 1999 to 2011, we find that larger board networks are associated with higher credit ratings than both firm financial data and probabilities of default predict. Near-investment grade firms improve their forward-looking ratings when their board is more connected. Lastly, we find that larger director networks are more beneficial during recessions, and times of increased financial uncertainty. Our results are robust to controls for endogeneity. Tests confirm that causality runs from connected boards to credit ratings.
\end{abstract}

* Corresponding author. Phone - 505-277-3207

Keywords: Director Networks, Social Capital, Credit Ratings, Board Connectivity JEL Classifications: G32, G24

${ }^{\dagger}$ We benefited by comments from an anonymous referee, the editor Srinivasan Krishnamurthy, Greg Nagel, Hong
Qian, and Xiaoxin Wang Beardsley. We thank the University of New Mexico Center for Advanced Research
Computing for computational resources. We are grateful to Steve Koch of Epic Software for the software codes. We
welcomed comments from conference participants at the Eastern Finance Association 2017, Southwestern Finance
Association 2017, and Southern Finance Association 2016. Jing Zhao gratefully acknowledges financial support
from The Cameron Research Fellowship in Finance at School of Business Administration, Portland State University. 


\section{Introduction}

Credit rating agencies (CRAs) attempt to correctly predict default risk and assign accurate ratings in the presence of asymmetric information between management and the rating agency. One tool that CRAs use to close this information gap is the quality and qualifications of top management and the board of directors of the firm they are rating. For example, Frost (2007) shows that CRAs rely on qualitative information when assessing credit ratings. Huang, Chen, Hsu, Chen and Wu (2004) show that purely financial empirical models do not fully capture firm ratings due to the subjective nature of the rating process. Similarly, Odders-White and Ready (2006) show that a rating contains information that is not fully depicted in a firm's financials. For instance, Khatami, Marchica and Mura (2016), find that direct personal connections between directors and CRAs result in higher credit ratings than fundamentals suggest. They reveal that CRAs rely on these connections to reduce information asymmetry, resulting in a more favorable credit rating.

We extend Khatami, Marchica and Mura (2016), who focus on direct connections between CRAs and directors (direct information channel), by examining the role of each director's overall network (indirect reputation channel or trust channel) in the credit rating decision. We argue that this reputation channel also provides important information about the quality of the board of directors, based on the size and characteristics of the director's network. Our research builds on the concept of social capital (Putnam, 1995; Rothstein, 2000), or that the number and importance of one's social connections influence the perceived trustworthiness and reputation. Belliveau, O'Reilly and Wade (1996) define social capital as “an individual's personal network." Paldam (2000) argues that the "deepest definition of social capital deals with trust." The foundation of that trust is the perceived reputation that everyone will do his or her 
part, behave well and adhere to a sense of duty. We predict that directors with larger and more influential networks have greater social capital. This reduces information asymmetry between the CRA and the firm, leading to a higher credit rating. Lu, Chen, and Liao (2010) find that investors demand higher credit spreads under conditions of information asymmetry and information uncertainty. Conversely, research supports the concept of connections increasing information flow and reducing information asymmetry (Omer, Shelley, and Tice; 2014, Custódio and Metzger; 2013, Renneboog and Zhao, 2011 and 2014, Ishii and Xuan, 2014; Cohen, Frazzini and Malloy, 2010; and Fracassi, 2008).

Directors with larger networks are better monitors and advisors due to their information and professional advantage (Coles, Wang, and Zhu, 2015). Boards with larger networks have been shown to make better decisions regarding CEO replacement and appointment (Coles, Wang, and Zhu, 2015), acquisitions (Schonlau and Singh, 2009), and improve firm performance (Geletkanycz and Boyd, 2011; Larcker, So, and Wang, 2013). Engelberg, Gao, and Parsons (2012) also find that connected boards provide economic value and lower the interest rates charged by banks. Chuluun, Prevost, and Puthenpurackal (2014) find that better-connected boards lead to lower spreads. Javakhadze, Ferris, and French (2016a) show that greater social capital improves financial development by reducing the impediments to external financing. Javakhadze, Ferris and French (2016b) find that direct connections between directors, senior management, and financiers reduce financial constraints and sensitivity of external financing to cash flow. Larger director networks also arise because a director has greater talent, expertise, and experience. All of this suggests that connected directors improve monitoring, reduce wasteful spending, and conserve cash. This benefits bondholders and improves the credit rating of the 
firm. Well-connected directors also indirectly certify the quality of the firm. CRAs can incorporate this certification when making rating decisions.

An alternative view, states that larger director networks are associated with lower credit ratings. Directors with larger networks are more likely to be busy directors, making them worse monitors or advisors (Fich and Shivdasani, 2006). The reason for this is because of time constraints, event conflicts, and directors' effort constraints (Ferris, Jagannathan, and Pritchard, 2003). For instance, busy boards are associated with poor firm performance (Ahn, Jiraporn, and Kim, 2010; Andres, Bongard, and Lehmann, 2013; Fich and Shivdasani, 2006; Jiraporn, Kim, and Davidson, 2008). Research also finds that busy boards have low board meeting attendance (Jiraporn, Davidson, DaDalt, and Ning, 2009), a greater likelihood of financial statement fraud (Beasley, 1996), and weaker corporate governance (Fich and Shivdasani, 2006; Andres, Bongard, and Lehmann, 2013). Thus, well-connected boards can reduce monitoring by increasing board busyness. This can lead to lower credit ratings assigned by CRAs.

Our results are more consistent with a reputational and monitoring effect of director networks. Using a sample of 11,172 firm-year observations from 1999 to 2011, we find that larger board networks are associated with higher credit ratings than predicted by both firm financial data and probabilities of default. The effect of director networks is greater in firms just below investment rating. Near-investment grade firms improve their forward-looking ratings when their board is more connected. Lastly, we find that better connected boards are more beneficial during recessions, and times of increased financial uncertainty. Our results are robust to controls for endogeneity. Our tests confirm that causality runs from connected boards to credit ratings. 
We contribute to the literature in several ways. First, we demonstrate that the size and relative importance of a board's network and its social capital, influences credit ratings. While other disciplines explore the concept of social capital, including economics, sociology and management (Adler and Kwon, 2002), we are the first to argue that social capital influences credit ratings.

Second, we show that indirect reputation channels also matter in debt contracts. Previous literature focuses on only the direct connections between the agents in debt contracts, or the direct connection of the agents of entity A to the agents of entity B (the rating firm or financier). Karolyi (2013) argues that business relationships form between the agents within two entities, not between the entities themselves. Consistent with this view, we show that boards with larger and more influential overall networks, over and above, direct ties to rating agencies or financial firms, improve credit ratings. ${ }^{1}$ This is consistent with Larcker, So, and Wang (2013) who take a "bird's eye" view of social capital when they find that well-connected boards outperform less central boards when examining risk-adjusted returns.

\section{Background, motivation, and hypothesis development}

\subsection{Board Connections, social capital, and credit ratings}

\footnotetext{
${ }^{1}$ We acknowledge that our measures of board connectivity might also include direct connections to CRAs, the direct channel. For example, it is possible that the network includes directors with present or past CRA employment experience (CRA director). It is also possible that some directors have connections to CRA directors. This would bias our findings. To address this issue we scanned our network of 5.5 million connections to isolate (1) CRA directors, and (2) those directors connected to CRA directors. First, the number of firm-year observations with CRA directors is only $2 \%$ (225 out of 11172) of our final sample and the number of unique firms with CRA directors is $3 \%$ (49 out of 1652). Second, the number of firm-year observations with board connections to CRA directors is only $2 \%$ (160 out of 11172) of our final sample and number of unique firms with board connections to CRA directors is 3\% (19 out of 1652). In total, our firm-year sample with CRA directors and directors connected to CRA directors is $3.4 \%$ (385 out of 11172), and the number of firms with CRA directors and directors connected to CRA directors is only $4.1 \%$ (68 out of 1652). Therefore, our results do not appear to be driven by the direct channel.
} 
Prior studies suggest that greater board connections are associated with better credit ratings due to the perceived reputation of well-connected directors and the trust built through such connections (Khatami, Marchica, and Mura, 2016). Similarly, directors with larger networks are better monitors and advisors due to their information and professional advantages (Coles, Wang, and Zhu, 2015). Prior research also finds that boards with greater connections make better decisions regarding CEO replacement and appointment (Coles, Wang, and Zhu, 2015), acquisitions (Schonlau and Singh, 2009), and have a positive effect on firm value and stock performance (Goldman, Rocholl, and So, 2009). Further, Larcker, So, and Wang (2013) show that board connections are associated with a higher return on assets and future growth.

Larger networks can arise because a director has greater talent, expertise, and experience which contribute to a higher reputation and greater social capital. Well-connected directors also indirectly certify the quality of the firm. CRAs may incorporate this certification when making rating decisions. Namely, the final credit rating decision depends on both financial and qualitative data. ${ }^{2}$ The experience of the rater and the history of the firm are just two qualitative items that influence a rating decision. A rating also involves a dialogue between the rating team and the firm over time. Rating agents act as partners in the rating process, providing continued feedback to allow the firm to best position its newest debt issuance. Karolyi (2013) finds that stronger personal and institutional relationships between parties in a debt contract benefit borrowers in the form of higher loan amounts, lower spreads, and fewer covenant restrictions. Fogel, Jandik, and McCumber (2014) examine CFO connectivity and the cost of private debt. They find that highly connected CFOs result in a 24\% (30 bps) reduction in loan spread compared to lower connected CFOs. Better-connected boards have also been shown to lead to

\footnotetext{
${ }^{2}$ See http://www.spratings.com/en_US/understanding-ratings for a review of S\&Ps rating process.
} 
lower spreads (Chuluun, Prevost, and Puthenpurackal, 2014), improved financial development (Javakhadze, Ferris, and French, 2016a), and reduced financial constraints and sensitivity of external financing to cash flow (Javakhadze, Ferris, and French, 2016b).

All of this suggests that connected directors improve monitoring, reduce wasteful spending, and conserve cash. This benefits bondholders and improves the credit rating of the firm. Thus, our first hypothesis predicts that directors with larger and more influential networks have greater social capital. This improves board monitoring and reduces information asymmetry between the CRA and the firm, leading to a higher credit rating.

$H_{1}$ : Larger and more influential board networks are associated with high credit ratings.

\subsection{Board connections, board busyness, and credit ratings}

Alternatively, larger director networks can also be associated with lower credit ratings. Directors with larger networks are more likely to be busy directors. Busy directors are worse monitors or advisors (Fich and Shivdasani, 2006) because of time constraints, event conflicts, and directors' effort constraints (Ferris, Jagannathan, and Pritchard, 2003). For instance, busy boards are associated with poor firm performance (Ahn, Jiraporn, and Kim, 2010; Andres, Bongard, and Lehmann, 2013; Fich and Shivdasani, 2006; Jiraporn, Kim, and Davidson, 2008;

Omer, Shelley, and Tice, 2014). Busier boards also have lower board meeting attendance (Jiraporn, Davidson, DaDalt, and Ning, 2009), a greater likelihood of financial statement fraud (Beasley, 1996), and weaker corporate governance (Fich and Shivdasani, 2006; Andres, Bongard and Lehmann, 2013). This suggests that well-connected boards may actually reduce monitoring by increasing board busyness. This can lead to lower credit ratings assigned by CRAs. Thus, our alternative hypothesis predicts that well-connected boards are associated with increased board 
busyness. This reduces board monitoring and increases information asymmetry between the CRA and the firm, leading to a lower credit rating.

$H_{1 a}:$ Larger and influential board networks are associated with lower credit ratings.

\section{Empirical Analysis}

\subsection{Test variables - Centralities}

Belliveau, O’Reilly, and Wade (1996) and Putnam (1995) define social capital as a person's social network. Individuals accrue social capital by developing a large network of associations. A network is a figure or pattern of relationships formed by people via associations that evolve through their profession, education, recreation, and friends-family. Each individual is assumed to be a participant (node) who forms relationships (edge) with other participants creating a network. One can model or graph the relationships within a social network using the collection of nodes and links. Figure 1 illustrates a simple social network where each circle is called a node, characterizing the participant, and the lines are called edges, representing the relationships between participants. Some nodes are more important or powerful because of their relative position in the network. Nodes accrue power in the following manner. First, node A has the maximum number of connections in the network. Second, nodes A, B, C, D, E, and F are also important because they are on the shortest path connecting participants in the network. Third, nodes A and B are closer to other nodes in the network. Fourth, nodes I, J, E, D, and H are also important by virtue of their association with other important nodes such as nodes A and B.

\section{[Insert Figure 1 about here]}

According to graph theory, the first concept discussed above is degree centrality. Degree centrality measures the number of direct relations by every node and relates to power. A participant with many connections is assumed to be powerful because those connections can lead 
to valuable information exchange and increased trustworthiness. The second concept is termed as betweenness centrality. If participants serve as a bridge between others, those participants are placed on the shortest distance between them. For example, node F is on the shortest path between node $\mathrm{C}$ and $\mathrm{G}$. Nodes such as $\mathrm{F}$ can be privy to more information that they can quickly disseminate. The third concept is closeness centrality. Consider nodes F and D. Although both lie on the shortest paths between other nodes, node D is closer to other nodes in the network and can access more information than node F. Closeness centrality is the inverse sum of the shortest distance between a node and all other nodes in the network. Accordingly, nodes A and B are expected to have high closeness centrality. Finally, eigenvector centrality measures the importance of a node in the network by considering whether a node is connected to another highly-connected node. For example, node $\mathrm{H}$ is a loner, but it is important because $\mathrm{H}$ is connected to node A, who is powerful. We provide the mathematical formulas to calculate the different centralities in Appendix 1.

The necessary data to construct our network graph comes from Boardex and spans years 1999 through 2011. We are interested in the social capital of directors as measured by their connectivity. In our research, we characterize the nodes by directors and the links by the relationships they develop. We create the network of directors using only their professional relationships. We assume the director develops direct relationships with board members in the same company. Directors in one company can also be members of the Board of Directors at other companies. Directors who represent multiple boards are also assumed to develop direct connections with board members in the other companies. For instance, let us assume that there are two public companies - company A and company B (see Figure 2). We create the direct connections between each director. The whole graph with direct and indirect connections (such 
as between director 2 and director 4) is projected. Using these projected graphs, we compute the four centrality measures using the Stanford Network Analysis Platform (Leskovec and Sosič, 2016) and Networkit (Staudt and Meyerhenke, 2016) software. One could argue that multiple directorships of directors could be a proxy for social capital. As described in this section, each centrality measures captures a different angle of connectivity or social capital. We will jeopardize the richness and depth of analysis if we just use multiple directorships as a proxy for social capital. We later show the differential effect of each centrality measure on credit ratings. Once the centralities have been computed we focus our efforts on US listed firms only. We average the director level centrality measures to obtain the board level centrality measures. One of the drawbacks of the BoardEx database is that it does not provide any standard firm identifier such as CUSIP, GVKEY, CIK, or ticker symbol. Hence, we match firms in BoardEx with COMPUSTAT using a name match fuzzy logic algorithm. We are able to match 6,756 firms between BoardEx and COMPUSTAT and obtain 41,855 firm-year observations. We obtain credit rating information for 11,172 firm-year observations.

\subsection{Dependent variables and other control variables}

Our dependent variable, Rating, is the variable SPLTICRM from COMPUSTAT. We create an inverse coding system starting with "AAA" rating which we code as 1 and a rating of "C" attains a numerical rating of 21(see Appendix 3). Following the convention in recent credit

rating papers (Kisgen, 2006; Kisgen and Strahan, 2010; Behr, Kisgen, and Taillard, 2015), firms with "D", "SD" rating, and firms without a rating are dropped from the sample. Firms with a "SD" and "D" rating are already in default and could have petitioned for bankruptcy, perhaps contaminating our sample. Our final sample size is 11,172 firm-year observations. 
We employ control variables as mentioned in Behr, Kisgen, and Taillard (2015) and Blume, Lim, and Mackinlay (1998). Specifically, we employ firm Size, Leverage, Interest Coverage, and Operating Margin. Following Behr Kisgen, and Taillard (2015) and Blume, Lim, and Mackinlay (1998), we expect credit ratings to be positively correlated to size, interest coverage and operating margin; and negatively correlated to leverage. In addition to the abovementioned control variables, we add additional controls for board and managerial talent. It can be argued that our results are picking up some omitted variables associated with boards or managerial ability. Therefore, we introduce several managerial and board-related controls to alleviate these concerns. Specifically, we introduce Board Tenure, Board Age, and Managerial Ability. We control for corporate governance by introducing three more variables - Board Size, Board Independence, and E-index. Please refer to Appendix 2 for definitions of the variables.

\section{Results}

\subsection{Descriptive statistics}

Table 1 presents summary statistics for the full sample. The mean (median) firm in our sample has Assets of $\$ 8,954(\$ 3,155)$ million. Firms carry $16.67 \%(6.64 \%)$ as cash balances and spend, on average, $7.37 \%(3.61 \%)$ of their total assets on capital expenditure. The mean (median) market-to-book ratio is $2.23(1.80)$. So far, the results from the summary statistics of the sample suggest that, on average, the firms in our sample are large firms with ample cash balances and superior market valuation. The mean (median) Leverage for firms in our sample is $67 \%(66 \%)$. The firms in our sample are highly profitable with an average (median) ROA of $11.78 \%(11.27 \%)$, and operating margin of $18.26 \%(15.25 \%)$.

[Insert Table 1 about here] 
Panel A of Table 2 presents the univariate statistics for our centrality variables. The centralities are normalized to the entire network; hence, we find extremely small values. Normalization allows for comparison of nodes of different sizes (Chuluun, Prevost, and Puthenpurackal, 2014; El-Khatib, Fogel, and Jandik, 2015). Additionally, the board level centralities are aggregated from individual director level centralities. We use the interpretation in Fogel, Ma, and Morck (2014) to explain our raw centrality variables. The mean (median) betweenness centrality is 0.00012 (0.00007), which means that the average director sits in about 8,300 paths. A director in the $75^{\text {th }}$ percentile sits in about 7,140 paths. The distributions seem to be positively skewed, which is not a surprise because only a limited number of directors reach stardom. The mean (median) value for closeness centrality is 0.3135 (0.3146). A closeness centrality measure of 0.3153 indicates that a typical director is about $(1 / 0.3153=3.71)$ degrees of separation from any randomly chosen director in the network. The mean (median) value for degree centrality is $0.00133(0.00107)$. Although degree centrality is normalized by the number of nodes in the network, a higher value means a larger number of connections. The mean (median) value for eigenvector centrality is $0.00160(0.00080)$. Eigenvector centrality does not provide an intuitive interpretation beyond our description in Appendix 2. A higher value certainly means that, on average, the directors are connected with other powerful directors in the network. Panel B presents the pairwise correlations between the centrality variables and ratings. Consistent with our hypothesis, we find that the centrality variables are positively correlated with ratings meaning that highly connected boards are associated with higher credit ratings. The centrality variables are positively correlated with themselves, suggesting that they measure similar, albeit different elements of centrality. Our results in Table 2 confirm the findings in Chuluun, Prevost, and Puthenpurackal (2014). 
[Insert Table 2 about here]

Table 3 presents univariate results of our main variable of interest, Rating, which is categorized by the four measures of centrality - betweenness centrality, closeness centrality, degree centrality, and eigenvector centrality. The results suggest that while each measure is calculated differently and measures different aspects of director centrality, the mean quartile scores are very similar across each of the four measures. For instance, the mean quartile value Rating in the lowest quartile for all the centrality measures is approximately 12 (BB rating) and for the highest quartile it is $9(\mathrm{BBB})$. These results suggest that a low centrality value for the board of directors is associated with noninvestment grade rating. As centrality increases, the noninvestment grade firms transition to investment grade. This could predict that highly central directors help firms just below the investment grade migrate to investment grade. We find additional support for this in Tables 7 and 8, presented later in this paper.

In Panel E of Table 3, we present the rating summary by industries. We use the FamaFrench 12 industry classification system. The industry with the best overall rating is Utilities, and the industry with the lowest overall rating is Telecom. We have a fairly representative set of observations into different industries where no one industry comprises more than $17 \%$ of the total sample. Consumer durables industry contributes lowest to the sample (6\%).

[Insert Table 3 about here]

\subsection{Connected boards and credit ratings}

We explore the relation between director and social capital, as measured by director centrality, and credit rating. We use a multiple regression model and the following regression equation, which includes two-way fixed effects (industry and time) and firm-level clustered standard errors: 


$$
\text { Rating }_{i t}=\beta_{1}(\text { Board centrality })_{i t}+\beta_{k}(\text { Controls })_{i t}+\varepsilon_{i t} \text {, }
$$

where credit rating is a function of board centrality (betweenness centrality, closeness centrality, degree centrality, and eigenvector centrality). We first control for Size, Leverage, Interest Coverage, and Operating Margin. As noted earlier, credit ratings are coded such that higher ratings have a lower number (e.g., $\mathrm{AAA}=1$ and $\mathrm{C}=21$ ). Since we have an inverted ordinal scale, we employ ordered probit for the multiple regression tests. To create a fluent interpretation, we standardize all our test variables (centralities). The controls variables are winsorized at the $5 \%$ level and further standardized. We predict that director connectivity measures will be negatively related to our credit rating variable.

Panel A of Table 4 reports the estimates of Equation (1). Model 1 includes betweenness, and the estimated coefficient is negative and significant at the 0.01 level. Firms with more connected directors have higher credit ratings. This provides support for our hypothesis which predicts that more connected directors will be associated with higher credit ratings. A one standard deviation increase in betweenness centrality improves the probability of better credit rating by 0.1239 units. Our results are similar using closeness centrality, degree centrality, and eigenvector centrality ${ }^{3}$. A one standard deviation increase in closeness centrality, degree centrality, and eigenvector centrality improves the probability of better credit ratings by 0.0747 , 0.1320 , and 0.0385 units, respectively. We perform marginal effects with unstandardized regressors. A three-unit increase in betweenness centrality improves credit rating by one full notch. One notch improvement in credit rating translates to 39 basis points (Kisgen and Strahan,

\footnotetext{
${ }^{3}$ Our results are robust to the exclusion of financials and utility firms.
} 
2010). Overall, we find that highly connected directors with substantial social capital are associated with higher credit ratings ${ }^{4}$.

The estimated coefficients on our control variables are also consistent with the expectations in Behr, Kisgen, and Taillard (2015). Size is positively associated with credit ratings. A one-standard deviation increase in Size improves the probability of better credit ratings by approximately a full notch. Higher leverage can make it difficult for a firm to pay back debt and increase the likelihood of bankruptcy. In line with this expectation, we find that an increase in leverage decreases the probability of credit rating by a quarter notch. Firms with better profitability (Operating Margin) and better capacity to repay debt (Interest Coverage) have better credit ratings. Higher Interest Coverage improves the probability of a better credit rating by 0.38 notch. And, higher Operating Margin improves the probability of a better credit ratings by 0.14 notch. The signs of the control variables are found to be consistent across all of our regressions. Therefore, we focus our attention on the test variables going forward.

\subsubsection{Board talent and corporate governance}

Our regression models may suffer from omitted variable bias. Board networks can proxy for other measures of board talent and corporate governance. To alleviate this concern, we include various board and corporate governance variables in our models. We present these results in Panel B of Table 4. Our results in model 2 and 3 are still robust to the inclusion of other proxies for board monitoring and talent.

[Insert Table 4 about here]

\subsection{Social capital and default prediction}

\footnotetext{
${ }^{4}$ We also used NScore (Larcker, So and Wang, 2013), and the first principal component calculated by performing the principal component analysis on the four centrality variables. NScore is computed as the average of the quartile values of all four centrality measures. We obtain results consistent with those in Table 4 and results are available upon request.
} 
A highly connected board benefits a firm in multiple ways such as access to advanced information, the expertise from managing different industries, and from the social capital that is derived from connections. Furthermore, connected directors can be seen as more trustworthy which could allow CRA agents to look past an alerting ratio.

We explore whether board connectivity influences the relationship between probability of default and credit rating. To capture default risk probabilities, we use default risk probability (DefaultProb) data from Bloomberg. The DRSK model uses the Merton approach to derive the distance to default (Cetina and Loudis, 2016; Nirei, Sushko, and Caballero, 2016). A smaller value indicates a larger distance to default with a lower default risk probability. Consequently, we expect a negative relationship between default probability and credit ratings. We interact default probabilities with centralities to see the differential effects of centrality and default risk probabilities on credit ratings. Specifically, we run the following model:

$$
\text { Rating }_{i t}=\beta_{1} \text { BoardCentrality }_{i t}+\beta_{2} \text { DefaultProb }_{i t}+\beta_{3} \text { DefaultProb * }
$$

Board Centrality $_{i t}+\beta_{k}(\text { Controls })_{i t}+\varepsilon_{i t}$

The regression results are reported in Table 5. In Panel A of Table 5, we find that DefaultProb is negatively related to firm ratings. A smaller distance to default means higher default probability and leads to lower credit ratings. All the board centrality measures are still positively related to firm ratings and are statistically significant. The positive association of board centrality measures with credit ratings, after controlling for default probability, is consistent with the notion that firms with highly connected boards can still achieve better credit ratings even with a higher default risk probability. To further explore the effect of default risk probabilities, we create terciles of default risk probability - Low, Medium, and High Default zones. In Table 5, Panel B, we rerun Equation (2), but without DefaultProb and interaction term. 
In the distress zone (Models 9 -12), we find that closeness and degree centralities are positively related to credit ratings and are significant at the 5\% and $1 \%$ level. In the medium default zone (Models 5-8), we find that betweenness, closeness, and degree centralities are positively related to credit ratings and are significant at the $1 \%$ level. In the safe zone (Models $1-4$ ), we show that betweenness, and degree centralities are positively related to credit ratings and are significant at $1 \%$ level. This suggests that the relation between centrality and credit ratings is not as strong in the safe zone as in the grey zone. The results in Table 5, Panel B, lend support to our hypothesis that social capital alleviates some concerns that financial information may not alleviate. Firms in the grey zone are those most likely to benefit from a highly central board to alleviate CRA concerns. Conversely, firms with very low default probability could have lower financial concerns. Consistent with this view, our results indicate that higher director centralities improve credit ratings, and that the relation is strongest for firms with moderately higher default probabilities ${ }^{5}$. In Table 5, Panel C, we present the results of Equation (3). Rating $_{i t}=\beta_{1}$ DefaultProbDum $+\beta_{2}$ Board Centrality ${ }_{i t}+\beta_{3}$ BoardCentrality $*$ DefaultProbDum $_{i t}+\beta_{k}(\text { Controls })_{i t}+\varepsilon_{i t}$

DefaultProbDum is an indicator variable equal to one if the observation falls in the "high default' probability zone. We interact this variable with each of the centrality variables. and as expected, we find that firms in the safe zone enjoy higher credit ratings relative to those in the distress zone. Further, we find that coefficients on betweenness and degree centralities remain negative and significant meaning that firms with more connected directors have higher credit ratings. The only significant interaction we see is between closeness centrality and the default

\footnotetext{
${ }^{5}$ We tested for the statistical differences between the centrality coefficients in table 5 panel B. Except eigenvector centrality we see that the coefficients are statistically different for a majority of the comparisons (available upon request).
} 
probability dummy variable. Overall, the results in Table 5 support our hypothesis that board connectivity improves credit ratings. This effect is much stronger in firms with moderately higher default probabilities suggesting that connected boards can serve to partially alleviate concerns of ratings agencies in the presence of a marginal financial picture ${ }^{6}$.

[Insert Table 5 about here]

\subsection{Social capital and NBER recessions}

We show that well-connected boards lead to higher credit ratings. We now explore the influence of social capital on credit ratings during NBER recessions by testing the moderating effect of recessions on the relation between board connectivity and credit ratings. Karolyi (2013) finds the value of personal relationships in lending agreements to be economically larger during NBER recessions. Auh (2014) shows that ratings standards are different in times of economic expansion versus economic recession. Specifically, credit ratings are overly pessimistic during economic downturns and overly optimistic during economic upturns. This suggests that the business cycle materially influences credit ratings. Bolton, Freixia, and Shapiro (2012) show that this phenomenon is the result of rating agencies offering higher ratings during economic booms to win business, as the risk of default in an expansionary business cycle is likely reduced, and the potential for a harmful rating abridged. We predict that the value of social capital derived from board connections will be more pronounced during recessions since these are the times of highest uncertainty. We explore the relation between board connectivity and credit rating using a multiple regression model using the following regression equation:

$$
\begin{aligned}
& \text { Rating }_{i t}=\beta_{1}(\text { Board Centrality })_{i t}+\beta_{2}(\text { Recession })+\beta_{3}(\text { Board Centrality } * \text { Recession })_{i t}+ \\
& \beta_{k}(\text { Controls })_{i t}+\varepsilon_{i t}
\end{aligned}
$$

\footnotetext{
${ }^{6}$ We performed Table 5 with Altman's (1968) ZScore and found similar results (available upon request).
} 
Regression Equation ${ }^{7}(4)$ is estimated where Rating is a function of proxies for board centrality, an indicator for Recession, an interaction term between director centrality terms and recession, and firm level controls.

Table 6 reports the results of tests for a moderating effect of recessions on the relationship between director centrality and credit rating. Model 1 includes betweenness centrality and the interaction term. The estimated coefficient on betweenness centrality and the interaction term shows a positive and significant relationship at the $1 \%$ level. During recessionary periods, information asymmetry can also increase making qualitative information more valuable. Taken together, these results suggest that during recessions, the positive effect of connected directors on credit rating is stronger, and that highly connected boards improve ratings during an economic downturn. These results align with our theoretical expectations. Models 2 , 3, and 4 include closeness centrality, degree centrality, and eigenvector centrality, along with their interactions with recession. Our results are robust and statistically significant except for the interaction term in Model 4 with eigenvector centrality. Overall, these results suggest that firms which employ boards with more social capital have higher credit ratings during recessions.

[Insert Table 6 about here]

\subsection{Social capital and investment grade rating}

The importance of investment grade rating has been shown (Kisgen, 2006; Boot, Milbourn, and Schmeits, 2006; Partnoy, 1999; Cantor and Packer, 1997). Boot, Milbourn, and Schmeits highlight pension fund guidelines that often prohibit holding securities below investment grade. Kisgen and Strahan (2010) show that a loss of an investment grade rating materially affects the cost of debt and bond prices at the investment grade cut-off, more so than

\footnotetext{
${ }^{7}$ We do not include the time fixed effects in this model because the recession dummy captures a time trend.
} 
at other rating levels. They similarly suggest the effect is due to the loss of institutional investors who are constrained by contracts that only allow for investment grade holdings. Alternatively, Kemper and Rao (2013) demonstrate that firms do not necessarily place great importance on the investment grade rating when making capital structure decisions. In this section, we examine whether board connectivity is related to investment grade ratings, examining the difference in board composition of firms around this hallowed line.

The results in Table 5 show that firms in distress benefit from a highly-connected board. We further investigate this issue along the investment grade cut-off line. A shift across this line is associated with larger changes in debt costs than at any other rating levels (Kisgen and Strahan, 2010). Therefore, we study the effect of board connectivity on firms that are on the edge of investment grade classification. By adding connected directors, firms just below investment grade (BB+, $\mathrm{BB}$, and $\mathrm{BB}-)$ can benefit more than those that are financially weaker $(<$ BB-). Therefore, we rerun our analysis using the specification in Table 4 on a subset of firms near investment grade and those that are just-above investment grade (BBB+, BBB, and $\mathrm{BBB}-)$.

Table 7 presents the results of our analysis. Comparing the coefficients for centralities, except for eigenvector centrality, Table 7 indicates that board centrality has an effect on firms that are just above investment grade; but we are unable to find an effect of centrality on firms that are just below investment grade. This result seems quite puzzling and warrants a further investigation given the evidence in Tables 5 and 6.

[Insert Table 7 about here]

Therefore, we examine the current year, one-year, and two-year forward-looking Ratings of firms that were just below investment grade the previous year. We split the sample into quartiles of centralities. Panel A of Table 8 presents the results for all firms that were rated 
below investment grade in the previous year. Although not monotonic, we generally find that the current year, one-year and two-year forward-looking Ratings do improve as we move into higher quartiles of centralities. For instance, we find that for betweenness centrality, the current year Rating is between BB- and BB in the lowest quartile. As we move to the highest quartile of betweenness centrality, we find that the current year Rating is between $\mathrm{BB}$ and $\mathrm{BB}+$. We witness a similar trend with the one-year and two-year forward-looking Ratings. It is encouraging that within a period of three years, firms with connected directors that were rated below investment grade nearly achieve investment grade status, enabling access to institutional investors and improving liquidity and returns for bondholders. In Table 8, Panel A, another trend arises when we examine the migration of Ratings along the row (i.e., the time trend for the same quartile). For instance, the Rating in the highest quartile for betweenness centrality consistently improves across the time period. This trend is also consistent among different quartiles of betweenness centrality. Except for the first quartiles of the other centrality measures, we find that this trend is consistent, which suggests that a highly connected board benefits a firm in the form of improved credit ratings.

In Panel B of Table 8, we examine the Ratings of firms that rose to investment grade that were rated as below investment grade in the previous year. For firms that are in the lowest quartile of betweenness centrality, some firms raise their Rating to between A and A-. For firms that are in the second and third quartile of betweenness centrality, we see a rise in Ratings to between $\mathrm{BBB}+$ and $\mathrm{BBB}$. Firms with highly connected boards, as measured by betweenness centrality, show an improvement in Ratings to between A- and BBB+. However, a trend ensues when we examine the time trend among different quartiles of centralities. There is a systematic degradation in Ratings moving along time for any quartile of centrality. 
Next, we present a multiple regression model in Panels C \& D of Table 8. In Panel C, we find consistent results for betweenness centrality. Future ratings improve in firms below investment grade in the previous year with more connected boards. In Table 8, Panel D, we examine the Ratings of firms that migrate to investment grade from noninvestment grade a year earlier. All the centrality measures are negatively related to credit rating variable. This suggests that highly connected boards are instrumental in helping firms achieve an investment grade rating $^{8}$.

[Insert Table 8 about here]

\subsection{Endogeneity}

Firms can hire highly connected directors to improve ratings. Thus, well-connected directors can search for directorships with firms that have better credit ratings. Therefore, director connectivity can be endogenously linked to credit ratings (Hermalin and Weisbach, 2003). Our results could be influenced by an omitted variable correlated with our connectivity measure that also affects ratings. We control for the simultaneity bias (reverse causality) and the omitted variable bias in multiple ways. First, as is popular in other studies, we lag the independent test variables and estimate Equation (1). This method is not without caveats (Bellemare, Masaki, and Pepinsky, 2015; Reed, 2013). One of the criteria for this method to adequately control for simultaneity bias is that the independent variable should be a stationary process (i.e., should not display any serial correlation). We test for the stationary of our board centralities using the Fisher's test in panel data. The test supports that the centrality variables are stationary. We proceed to estimate Model 1 with lagged values of the standardized board

\footnotetext{
${ }^{8}$ In general, we found that board centrality increases only when boards add directors with higher centrality. We replicated table 8 panels $\mathrm{C} \& \mathrm{D}$ with board member additions where board centrality increases. Results are consistent indicating that firms add board members with higher centrality, which in turn improves future credit ratings. Tables are available upon request.
} 
centralities and find that the results are unchanged up to two lags. Models $1-4$ in Table 9 present the results of our test with the lagged board centrality variables. All of the centrality variables suggest a positive relationship with credit ratings, confirming that causality runs from board connectivity and social capital to ratings. Second, we use an instrumental variables approach. A Hausman test for the residuals of Model 1 reveals that we cannot reject the null hypothesis of exogeneity. Hence, as in Omer, Shelley, and Tice (2014), we proceed to use median industry centralities as our instruments for board centralities. We use the industry median centrality as an instrumental variable because it is expected to be correlated to the board's centrality, but uncorrelated with the error term. The median centrality of the industry could determine the hiring of well-connected directors for firms in the particular industry, but the median centrality of the industry should not affect firm credit ratings. Board size could also determine board centralities (Renneboog and Zhao, 2011). In addition to industry median centralities we also used the industry median board size as our second instrumental variable. We find similar results as with one instrumental variable i.e., industry median centrality. We present the results of the second stage instrumental variable regressions in Models 5-8. We find that betweenness centrality and eigenvector centrality are still positively related to credit ratings. All our instruments are valid with $F$-values exceeding the Wald critical values at least at the $10 \%$ level, suggesting adequate instrument validity. Third, we perform a correlation test between credit ratings and the lagged value of board centralities for those firms whose board size does not change from the previous year ${ }^{9}$. We find that board centralities remain positively associated with credit ratings, supporting our earlier finding that a highly-connected board results in

\footnotetext{
${ }^{9}$ One could argue that board size can remain the same even when board members leave. For example, two new directors could replace two departing directors. In this case the board centralities could be different from the previous year. We acknowledge this as a potential limitation of this test.
} 
improved credit ratings. In untabulated results, we extend the correlation analysis to a regression model, wherein we estimate Equation (1) with lagged standardized board centralities for those firms without a change in board composition. We find that our results are unchanged. Except for eigenvector centrality, all other board centrality variables are positively related to credit ratings. In summary, our robustness tests in this section confirm that endogeneity does not influence our results.

[Insert Table 9 about here]

\section{Conclusion}

Credit ratings continue to be a heavily explored topic in the world of finance. Credit rating assignment is both qualitative and quantitative. We explore the effect of director social capital on firm credit ratings. We predict that the well-connected boards have greater social capital, which will lead to ratings that are more favorable.

Consistent with this view, we find well-connected boards lead to higher credit ratings. Our results are robust to controls for managerial talent and corporate governance. This suggests that well-connected boards can ease concerns of CRA agents in marginal firms. We also examine whether well-connected directors lead to ratings that are higher than their default probabilities predict. We find that well-connected directors associate with better credit ratings than predicted by financial models. Firms with higher default probabilities benefit more from connected boards.

Further, we explore the effect of connected directors on credit ratings during economic recessions. In times of economic downturns, the effect of director connectivity is highly valued. We find that firms employing boards with better connections, or greater social capital, have higher credit ratings during times of financial distress. Lastly, we examine firms near the 
investment grade cutoff. We find that firms with more well-connected boards are more likely to migrate above this threshold. The social capital of the board of directors helps influence the movement from noninvestment grade to investment grade.

Taken together, our results suggest that connected directors, those with substantial social capital, are a powerful ally in the pursuit of better credit ratings. To the extent that higher credit ratings associate with lower borrowing costs and greater access to financial markets, our findings suggest that firms that employ connected directors also benefit from lower borrowing costs and greater access to financial markets, all other things being equal. 


\section{References}

Adler, P.S. and S.W. Kwon, 2002. Capital: Prospects for a new concept, Academy of Management Review 27, 17-40.

Ahn, S., P. Jiraporn, and Y.S. Kim 2010. Multiple directorships and acquirer returns. Journal of Banking \& Finance 34, 2011-2026.

Altman, E. I., 1968. Financial ratios, discriminant analysis and the prediction of corporate bankruptcy, Journal of Finance 23, 589-609.

Andres, C., I. Bongard, and M. Lehmann, 2013. Is busy really busy? Board governance revisited. Journal of Business Finance \& Accounting 40, 1221-1246.

Auh, J.K., 2014. Essays on corporate credit, Working paper, Columbia University.

Beasley, M.S., 1996. An empirical analysis of the relation between the board of director composition and financial statement fraud, The Accounting Review 71, 443-465

Bebchuk, L., A. Cohen, and A. Ferrell, 2009. What matters in corporate governance? Review of Financial Studies 22, 783-827.

Behr, P., D.J. Kisgen and J.P. Taillard, 2015. Did government regulations lower credit rating quality, Working paper, Getulio Vargas Foundation.

Bellemare, M.F., T. Masaki and T.B. Pepinsky, 2015, Lagged explanatory variables and the estimation of causal effects, Working paper, University of Minnesota.

Belliveau, M.A., C.A. O'Reilly, III and J.B. Wade, 1996. Social capital at the top: Effects of social similarity and status on CEO compensation, Academy of Management Journal 39, 1568-1593.

Blume, M.E., F. Lim and A.C. Mackinley, 1998. The declining credit quality of US corporate debt: Myth or reality? Journal of Finance 53, 1389-1413.

Bolton, P., X. Freixas and J. Shapiro, 2012. The credit ratings game, Journal of Finance 67, 85111.

Boot, A. W., T.T. Milbourn and A. Schmeits, 2006. Credit ratings as coordination mechanisms, Review of Financial Studies 19, 81-118.

Cantor, R. and F. Packer, 1997. Differences of opinion and selection bias in the credit rating industry, Journal of Banking and Finance 21, 1395-1417.

Cetina, J. and B. Loudis., 2016. The influence of systemic importance indicators on banks' credit default swap spreads, Journal of Risk Management in Financial Institutions 9, 17-31. 
Cohen, L., A. Frazzini and C. Malloy, 2010. Sell-side school ties, Journal of Finance 65, 14091437.

Coles, J. L., A.Y. Wang, and C. Zhu. 2015. Director network and CEO turnover, Working paper, University of Utah.

Chuluun, T. A. Prevost and J. Puthenpurackal, 2014. Board ties and the cost of corporate debt, Financial Management 43, 533-568.

Custódio, C. and D. Metzger, 2013. How do CEOs matter? The effect of industry expertise on acquisition returns, Review of Financial Studies 26, 2008-2047.

Demerjian, P., B. Lev, and S. McVay. 2012. Quantifying managerial ability: A new measure and validity tests, Management Science 58, 1229-1248.

El-Khatib, R., K. Fogel and T. Jandik, 2015. CEO network centrality and merger performance, Journal of Financial Economics 116, 349-382.

Engelberg, J., P. Gao, and C. Parsons, 2012. Friends with money, Journal of Financial Economics 103, 169-188.

Ferris, S.P., M. Jagannathan, and A.C. Pritchard, 2003. Too busy to mind the business? Monitoring by directors with multiple board appointments, The Journal of Finance 58, 1087-1111.

Fich, E.M. and A. Shivdasani, 2006. Are busy boards effective monitors? The Journal of Finance, 61, 689-724.

Fogel, K., L. Ma, and R. Morck, 2014. Powerful independent directors, Working paper, Suffolk University.

Fogel, K., T. Jandik and W.R. McCumber, 2014. CFO network centrality and private debt, Working paper, Suffolk University.

Fracassi, C., 2008. Corporate finance policies and social networks, Working paper, University of Texas.

Frost, C.A., 2007. Credit rating agencies in capital markets: A review of research evidence on selected criticisms of the agencies, Journal of Accounting, Auditing and Finance 22, 469-492.

Geletkanycz, M.A. and B.K.Boyd. 2011, CEO outside directorships and firm performance: A reconciliation of agency and embeddedness views. Academy of Management Journal 54, 335352.

Goldman, E., J. Rocholl and J. So, 2009. Do politically connected boards affect firm value? Review of Financial Studies 22(6), 2331-2360. 
Hermalin, B.E. and M.S. Weisbach, 2003. Boards of directors as an endogenously determined institution: A survey of the economic literature (digest summary), Economic Policy Review 9 1726.

Huang, Z., H. Chen, C.J. Hsu, W.H. Chen, and S. Wu, 2004. Credit rating analysis with support vector machines and neural networks: A market comparative study, Decision Support Systems $37,543-558$.

Ishii, J., and Y. Xuan, 2014. Acquirer-target social ties and merger outcomes, Journal of Financial Economics 112, 344-363.

Javakhadze, D., S.P. Ferris, and D.W. French, 2016. Managerial social capital and financial development: A cross-country analysis. Financial Review 51, 37-68.

Javakhadze, D., S.P. Ferris, and D.W. French, 2016. Social capital, investments, and external financing, Journal of Corporate Finance 37, 38-55.

Jiraporn, P., Y.S. Kim, and W.N. Davidson, 2008. Multiple directorships and corporate diversification, Journal of Empirical Finance 15, 418-435.

Jiraporn, P., W.N. Davidson, P. DaDalt, and Y. Ning, 2009. Too busy to show up? An analysis of directors' absences, The Quarterly Review of Economics and Finance 49, 1159-1171.

Karolyi, S.A., 2013. Personal lending relationships, Working paper, Yale.

Kemper, K.J. and R.P. Rao, 2013. Do credit ratings really affect capital structure? Financial Review 48, 573-595.

Khatami, S.H., M.T. Marchica, and R. Mura, 2016. Rating friends: The effect of personal connections on credit ratings, Journal of Corporate Finance 39, 222-241.

Kisgen, D. J. and P.E. Strahan, 2010. Do regulations based on credit ratings affect a firm's cost of capital? Review of Financial Studies 23, 4324-4347.

Kisgen, D., 2006. Credit ratings and capital structure, Journal of Finance 61, 1035-1072.

Larcker, D.F., E.C. So, and C.C. Wang., 2013. Boardroom centrality and firm performance, Journal of Accounting and Economics 55, 225-250.

Leskovec, J. and R. Sosič, 2016. SNAP: A general-purpose network analysis and graph-mining library, ACM Transactions on Intelligent Systems and Technology 8, 1.

Lu, C.W., T.K. Chen and H.H. Liao, 2010. Information uncertainty, information asymmetry and corporate bond yield spreads, Journal of Banking and Finance 34(9), 2265-2279. 
Nirei, M., V. Sushko and J. Caballero., 2016. Bank capital shock propagation via syndicated interconnectedness, Computational Economics 47, 67-96.

Omer, T. C., M.K. Shelley and F.M. Tice, 2014. Do well-connected directors affect firm value? Journal of Applied Finance 24, 17 - 32.

Odders-White, E. R., and M. J. Ready, 2006. Credit ratings and stock liquidity, Review of Financial Studies 19,119-57

Paldam, M., 2000. Social capital: one or many? Definition and measurement, Journal of Economic Surveys 14(5), 629-653.

Partnoy, F., 1999. The Siskel and Ebert of financial markets: Two thumbs down for the credit rating agencies, Washington University Law Quarterly 77, 619-715.

Putnam, R. D., 1995. Bowling alone: America's declining social capital, Journal of Democracy $6,65-78$.

Reed, W.R., 2013. A note on the practice of lagging variables to avoid simultaneity, Working paper, University of Canterbury.

Renneboog, L. and Y. Zhao. 2011, US knows us in the UK: On director networks and CEO compensation, Journal of Corporate Finance 17, 1132-1157.

Renneboog, L. and Y. Zhao, 2014. Director networks and takeovers, Journal of Corporate Finance 28, 218-234.

Rothstein, B., 2000. Trust, social dilemmas and collective memories, Journal of Theoretical Politics 12, 477-501.

Schonlau, R.J. and P.V. Singh, 2009. Board networks and merger performance, Working paper, Carnegie Mellon University.

Staudt, C.L. and H. Meyerhenke, 2016. Engineering parallel algorithms for community detection in massive networks, IEEE Transactions on Parallel and Distributed Systems 27, 171-184. 


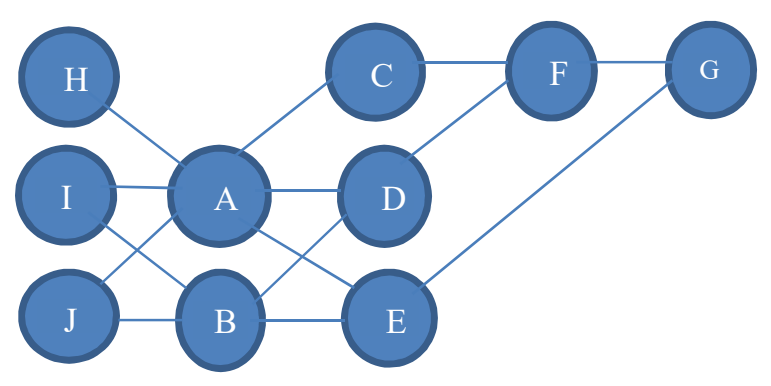

Figure 1 -

A simple illustration of a social network

This figure provides a simple illustration of a social network. Alphabets represent nodes or participants and the straight lines represent the connections between them.

\begin{tabular}{ll} 
Company A & Company B \\
\hline Director 1 & Director 4 \\
Director 2 & Director 5 \\
Director 3 & Director 1 \\
\hline
\end{tabular}

\begin{tabular}{ll}
\multicolumn{2}{c}{ Connection Links } \\
\hline Director 1 & Director 2 \\
Director 1 & Director 3 \\
Director 1 & Director 4 \\
Director 1 & Director 5 \\
Director 2 & Director 3 \\
Director 4 & Director 5 \\
\hline
\end{tabular}

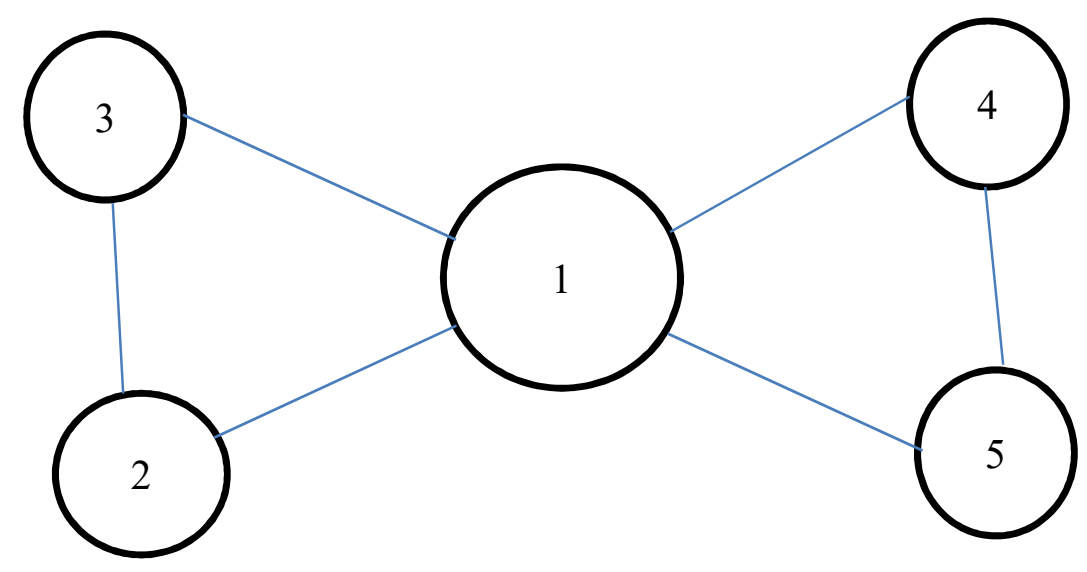

Figure 2

Network of directors

This figure depicts the connections between directors of two companies that share a director. 


\section{Table 1}

Summary Statistics - This table presents the summary statistics of the sample. Variables are defined in Appendix 2.

\begin{tabular}{lrrrr}
\hline Variable & MEAN & MEDIAN & STD DEV & $\mathrm{N}$ \\
\hline Rating & 10.3070 & 10.0000 & 3.4089 & 11172 \\
Assets (in millions) & 8954.0770 & 3155.7350 & 13248.6200 & 11172 \\
Tangibility & 0.5604 & 0.2505 & 0.6888 & 10664 \\
Cash & 0.1667 & 0.0664 & 0.2339 & 11172 \\
Capx & 0.0737 & 0.0361 & 0.0934 & 11172 \\
Mkbk & 2.2302 & 1.8025 & 1.7377 & 11172 \\
Leverage & 0.6739 & 0.6623 & 0.1792 & 11172 \\
Roa & 0.1178 & 0.1127 & 0.0659 & 10763 \\
Operating Margin & 0.1826 & 0.1525 & 0.1330 & 11172 \\
\hline
\end{tabular}


Table 2

Board network Centrality measures

This table provides the summary statistics for the centrality measures (non-standardized) for our sample. Panel A provides the summary statistics and panel B provides the pair-wise correlation tables of our centrality measures and Ratings.

\begin{tabular}{lccccc}
\hline \multicolumn{7}{l}{ Panel A-Network Measures } \\
\hline \multicolumn{7}{c}{ Mean } & SD & P25 & Median & P75 \\
\hline Between & 0.00012 & 0.00016 & 0.00004 & 0.00007 & 0.00014 \\
Closeness & 0.31353 & 0.01868 & 0.30231 & 0.31464 & 0.32625 \\
Degree & 0.00133 & 0.00099 & 0.00065 & 0.00107 & 0.00170 \\
Eigen & 0.00160 & 0.00274 & 0.00038 & 0.00080 & 0.00173 \\
\multicolumn{7}{c}{} \\
\hline Panel B - Pairwise Correlation of Centralities and Rating \\
\hline Between & $-0.3291^{* * *}$ & Between & Closeness & Degree \\
Closeness & $-0.2827^{* * *}$ & $0.5908^{* * *}$ & & \\
Degree & $-0.3417^{* * *}$ & $0.8170^{* * *}$ & $0.8113^{* * *}$ & \\
Eigen & $-0.1469^{* * *}$ & $0.3416^{* * *}$ & $0.4319^{* * *}$ & $0.5476^{* * *}$ \\
\hline
\end{tabular}

Coefficients significant at the $1 \%, 5 \%$, and $10 \%$ are marked by $* * *, * *, *$ respectively. 
Table 3

Ratings summary -

This table splits the ratings by quartiles of the four different board centralities - Betweenness, Closeness, Degree, and Eigenvector centrality. The quartiles were calculated each year since the network is dynamic.

\begin{tabular}{|c|c|c|c|c|}
\hline \multirow[t]{2}{*}{ Panel A: } & \multicolumn{4}{|c|}{ Betweenness centrality } \\
\hline & Mean & Median & SD & $\mathbf{N}$ \\
\hline \multicolumn{5}{|l|}{ Quartile } \\
\hline 1 & 11.8276 & 13.0000 & 3.2712 & 116 \\
\hline 2 & 11.2915 & 12.0000 & 3.0516 & 2336 \\
\hline 3 & 10.7114 & 11.0000 & 3.1578 & 5648 \\
\hline 4 & 8.7575 & 9.0000 & 3.5955 & 3072 \\
\hline \multicolumn{5}{|c|}{ Panel B: $\quad$ Closeness centrality } \\
\hline 1 & 11.9447 & 13.0000 & 2.8701 & 217 \\
\hline 2 & 11.2881 & 12.0000 & 3.0854 & 1982 \\
\hline 3 & 10.7542 & 11.0000 & 3.1094 & 5619 \\
\hline 4 & 8.8721 & 9.0000 & 3.6366 & 3354 \\
\hline \multicolumn{5}{|c|}{ Panel C: $\quad$ Degree centrality } \\
\hline 1 & 11.7039 & 12.0000 & 3.0513 & 179 \\
\hline 2 & 11.5061 & 12.0000 & 3.0176 & 2039 \\
\hline 3 & 10.6791 & 10.0000 & 3.0958 & 5666 \\
\hline 4 & 8.8461 & 9.0000 & 3.6681 & 3288 \\
\hline \multicolumn{5}{|c|}{ Panel D: $\quad$ Eigenvector centrality } \\
\hline 1 & 11.9087 & 13.0000 & 2.9140 & 241 \\
\hline 2 & 11.2038 & 12.0000 & 3.1031 & 2174 \\
\hline 3 & 10.7049 & 11.0000 & 3.1341 & 5700 \\
\hline 4 & 8.8011 & 9.0000 & 3.6483 & 3057 \\
\hline \multicolumn{5}{|c|}{ Panel E-Rating by industries } \\
\hline \multicolumn{2}{|r|}{ Industry } & $\begin{array}{c}\text { Median } \\
\text { Rating }\end{array}$ & $\begin{array}{r}\mathrm{Nu} \\
\mathrm{Obs}\end{array}$ & $\begin{array}{l}r \text { of } \\
\text { tions }\end{array}$ \\
\hline \multicolumn{2}{|c|}{ Consumer NonDurables } & BBB & & 667 \\
\hline \multicolumn{2}{|c|}{ Consumer Durables } & $\mathrm{BB}+$ & & 290 \\
\hline \multicolumn{2}{|c|}{ Manufacturing } & $\mathrm{BB}+$ & & 1511 \\
\hline \multicolumn{2}{|l|}{ Energy } & $\mathrm{BB}$ & & 701 \\
\hline \multicolumn{2}{|l|}{ Chemicals } & BBB- & & 511 \\
\hline \multicolumn{2}{|c|}{ Business Equipment } & $\mathrm{BB}$ & & 965 \\
\hline \multicolumn{2}{|c|}{ Telecom } & $\mathrm{B}+$ & & 465 \\
\hline \multicolumn{2}{|l|}{ Utilities } & $\mathrm{BBB}+$ & & 1044 \\
\hline \multicolumn{2}{|l|}{ Shops } & $\mathrm{BB}$ & & 1164 \\
\hline \multicolumn{2}{|l|}{ Healthcare } & $\mathrm{BB}$ & & 522 \\
\hline \multicolumn{2}{|l|}{ Finance } & BBB & & 1942 \\
\hline \multicolumn{2}{|l|}{ Other } & $\mathrm{BB}$ & & 1390 \\
\hline
\end{tabular}


Table 4

Ratings and board connectivity -

Panel A, presents the ordered probit regressions of ratings against standardized centralities and other control variables. The dependent variable is Rating. Variables are defined in Appendix 2. Panel B, extends the regressions in panel A to present the unified effect of talent and corporate governance. Two-way fixed effects with industry and year are employed with firm-level clustered standard errors. Control variables are winsorized at the 5\% level and then standardized. t-statistics in parenthesis.

Panel A: Ordered Probit regressions of Rating versus centralities and control variables

\begin{tabular}{|c|c|c|c|c|}
\hline & (1) & $(2)$ & (3) & (4) \\
\hline Variables & Rating & Rating & Rating & Rating \\
\hline Betweenness & $\begin{array}{c}-0.1239^{* * *} \\
(-4.1471)\end{array}$ & & & \\
\hline Closeness & & $\begin{array}{c}-0.0747 * * * \\
(-2.8031)\end{array}$ & & \\
\hline Degree & & & $\begin{array}{c}-0.1320^{* * *} \\
(-5.1095)\end{array}$ & \\
\hline Eigen & & & & $\begin{array}{c}-0.0385^{* *} \\
(-2.1200)\end{array}$ \\
\hline Size & $\begin{array}{c}-0.8520 * * * \\
(-22.0313)\end{array}$ & $\begin{array}{c}-0.8692 * * * \\
(-23.1858)\end{array}$ & $\begin{array}{c}-0.8443 * * * \\
(-22.2581)\end{array}$ & $\begin{array}{c}-0.8967 * * * \\
(-24.3518)\end{array}$ \\
\hline Leverage & $\begin{array}{c}0.2473 * * * \\
(9.4137)\end{array}$ & $\begin{array}{c}0.2479 * * * \\
(9.4717)\end{array}$ & $\begin{array}{c}0.2502 * * * \\
(9.5608)\end{array}$ & $\begin{array}{c}0.2441 * * * \\
(9.2805)\end{array}$ \\
\hline Interest Coverage & $\begin{array}{r}-0.3832 * * * \\
(-13.3422)\end{array}$ & $\begin{array}{c}-0.3834 * * * \\
(-13.2626)\end{array}$ & $\begin{array}{c}-0.3773 * * * \\
(-13.1256)\end{array}$ & $\begin{array}{c}-0.3876^{* * *} \\
(-13.4161)\end{array}$ \\
\hline Operating Margin & $\begin{array}{c}-0.1382 * * * \\
(-5.4549)\end{array}$ & $\begin{array}{c}-0.1419 * * * \\
(-5.5501)\end{array}$ & $\begin{array}{c}-0.1414 * * * \\
(-5.5786)\end{array}$ & $\begin{array}{c}-0.1361 * * * \\
(-5.3538)\end{array}$ \\
\hline Observations & 11,172 & 11,172 & 11,172 & 11,172 \\
\hline Industry FE & Yes & Yes & Yes & Yes \\
\hline Year FE & Yes & Yes & Yes & Yes \\
\hline Pseudo R-squared & 0.173 & 0.171 & 0.173 & 0.170 \\
\hline
\end{tabular}


Panel B: Regressions controlling for talent and governance

\begin{tabular}{|c|c|c|c|c|}
\hline & $(1)$ & $(2)$ & (3) & $(4)$ \\
\hline Variables & Rating & Rating & Rating & Rating \\
\hline Betweenness & $\begin{array}{c}-0.0258 \\
(-1.0357)\end{array}$ & & & \\
\hline Closeness & & $\begin{array}{l}-0.1081 * * \\
(-2.0473)\end{array}$ & & \\
\hline Degree & & & $\begin{array}{l}-0.0700 * \\
(-1.7224)\end{array}$ & \\
\hline Eigen & & & & $\begin{array}{c}-0.0022 \\
(-0.0762)\end{array}$ \\
\hline Size & $\begin{array}{c}-0.8590 * * * \\
(-13.4955)\end{array}$ & $\begin{array}{c}-0.8215 * * * \\
(-12.0896)\end{array}$ & $\begin{array}{c}-0.8319 * * * \\
(-12.3052)\end{array}$ & $\begin{array}{r}-0.8720 * * * \\
(-13.5243)\end{array}$ \\
\hline Leverage & $\begin{array}{c}0.1617 * * * \\
(2.7534)\end{array}$ & $\begin{array}{c}0.1705 * * * \\
(2.8967)\end{array}$ & $\begin{array}{c}0.1663 * * * \\
(2.8207)\end{array}$ & $\begin{array}{c}0.1595 * * * \\
(2.7155)\end{array}$ \\
\hline Interest Coverage & $\begin{array}{c}-0.3647 * * * \\
(-8.9800)\end{array}$ & $\begin{array}{c}-0.3587 * * * \\
(-8.9204)\end{array}$ & $\begin{array}{c}-0.3608 * * * \\
(-8.9335)\end{array}$ & $\begin{array}{c}-0.3657 * * * \\
(-8.9661)\end{array}$ \\
\hline Operating Margin & $\begin{array}{c}-0.1789 * * * \\
(-3.7250)\end{array}$ & $\begin{array}{c}-0.1826 * * * \\
(-3.8286)\end{array}$ & $\begin{array}{c}-0.1788 * * * \\
(-3.7405)\end{array}$ & $\begin{array}{c}-0.1799 * * * \\
(-3.7593)\end{array}$ \\
\hline Managerial Ability & $\begin{array}{c}-0.0526 \\
(-1.5373)\end{array}$ & $\begin{array}{c}-0.0485 \\
(-1.4103)\end{array}$ & $\begin{array}{c}-0.0495 \\
(-1.4469)\end{array}$ & $\begin{array}{c}-0.0532 \\
(-1.5478)\end{array}$ \\
\hline Board Tenure & $\begin{array}{c}-0.1538 * * * \\
(-3.8928)\end{array}$ & $\begin{array}{c}-0.1585 * * * \\
(-4.0062)\end{array}$ & $\begin{array}{c}-0.1570 * * * \\
(-3.9759)\end{array}$ & $\begin{array}{r}-0.1538 * * * \\
(-3.8926)\end{array}$ \\
\hline Board Age & $\begin{array}{c}-0.0270 \\
(-0.6573)\end{array}$ & $\begin{array}{c}-0.0321 \\
(-0.7809)\end{array}$ & $\begin{array}{c}-0.0285 \\
(-0.6935)\end{array}$ & $\begin{array}{c}-0.0286 \\
(-0.6975)\end{array}$ \\
\hline Board Size & $\begin{array}{c}-0.2646 * * * \\
(-5.6570)\end{array}$ & $\begin{array}{c}-0.2619 * * * \\
(-5.5633)\end{array}$ & $\begin{array}{c}-0.2636 * * * \\
(-5.6381)\end{array}$ & $\begin{array}{c}-0.2677 * * * \\
(-5.6982)\end{array}$ \\
\hline Board Independence & $\begin{array}{c}-0.1407 * * * \\
(-3.9055)\end{array}$ & $\begin{array}{c}-0.1158 * * * \\
(-3.2039)\end{array}$ & $\begin{array}{c}-0.1295 * * * \\
(-3.5993)\end{array}$ & $\begin{array}{c}-0.1451 * * * \\
(-4.0946)\end{array}$ \\
\hline E-Index & $\begin{array}{c}-0.0136 \\
(-0.3323)\end{array}$ & $\begin{array}{c}-0.0116 \\
(-0.2831)\end{array}$ & $\begin{array}{c}-0.0159 \\
(-0.3873)\end{array}$ & $\begin{array}{c}-0.0144 \\
(-0.3501)\end{array}$ \\
\hline Observations & 3,146 & 3,146 & 3,146 & 3,146 \\
\hline Industry FE & Yes & Yes & Yes & Yes \\
\hline Year FE & Yes & Yes & Yes & Yes \\
\hline Pseudo R-squared & 0.174 & 0.174 & 0.174 & 0.174 \\
\hline
\end{tabular}

Coefficients significant at the $1 \%, 5 \%$, and $10 \%$ are marked by $* * *, * *, *$ respectively. 
Table 5 -

\section{Ratings, board connectivity and probability of default -}

This table presents the combined effect of probability of default and standardized centralities on ratings. Panel A presents the results of Equation 2. Panel B presents the sub-sample regressions of Ratings on centralities and other control variables. We split the sample into tertiles of Default Probability. DefaultProbDum is a dummy variable that takes the value of 1 if the firm belongs to the High Default Probability category. We interact this dummy variable with board centralities are present the regression results in Panel C. Variables are defined in Appendix 2. Two-way fixed effects with industry and year are employed with firm-level clustered standard errors. Control variables are winsorized at the 5\% level and then standardized. t-statistics in parenthesis.

Panel A: Regressions of ratings on probability of default

\begin{tabular}{|c|c|c|c|c|}
\hline & (1) & (2) & (3) & (4) \\
\hline Variables & Rating & Rating & Rating & Rating \\
\hline DefaultProb & $\begin{array}{c}13.6741^{* * *} \\
(5.1965)\end{array}$ & $\begin{array}{c}13.7375^{* * *} * \\
(5.3555)\end{array}$ & $\begin{array}{c}13.8429 * * * \\
(5.0066)\end{array}$ & $\begin{array}{c}13.8690 * * * \\
(5.2014)\end{array}$ \\
\hline Between & $\begin{array}{c}-0.1031 * * * \\
(-2.7320)\end{array}$ & & & \\
\hline Between*DefaultProb & $\begin{array}{c}-1.2180 \\
(-0.4326)\end{array}$ & & & \\
\hline Closeness & & $\begin{array}{c}-0.1250 * * * \\
(-3.0798)\end{array}$ & & \\
\hline Closeness*DefaultProb & & $\begin{array}{c}-0.8482 \\
(-0.3802)\end{array}$ & & \\
\hline Degree & & & $\begin{array}{c}-0.1583 * * * \\
(-4.4037)\end{array}$ & \\
\hline Degree*DefaultProb & & & $\begin{array}{c}-0.3231 \\
(-0.1069)\end{array}$ & \\
\hline Eigen & & & & $\begin{array}{l}-0.0550^{*} \\
(-1.9402)\end{array}$ \\
\hline Eigen*DefaultProb & & & & $\begin{array}{c}0.2456 \\
(0.0789)\end{array}$ \\
\hline Size & $\begin{array}{c}-0.5833 * * * \\
(-14.8255)\end{array}$ & $\begin{array}{c}-0.5757 * * * \\
(-14.7413)\end{array}$ & $\begin{array}{c}-0.5631 * * * \\
(-14.4069)\end{array}$ & $\begin{array}{c}-0.6154 * * * \\
(-16.5290)\end{array}$ \\
\hline Leverage & $\begin{array}{c}1.0920^{* * *} \\
(4.4291)\end{array}$ & $\begin{array}{c}1.1038 * * * \\
(4.5322)\end{array}$ & $\begin{array}{c}1.1313 * * * \\
(4.6273)\end{array}$ & $\begin{array}{c}1.0800 * * * \\
(4.3862)\end{array}$ \\
\hline Interest Coverage & $\begin{array}{c}-0.0500 * * * \\
(-9.4583)\end{array}$ & $\begin{array}{c}-0.0489 * * * \\
(-9.2438)\end{array}$ & $\begin{array}{c}-0.0480 * * * \\
(-9.1092)\end{array}$ & $\begin{array}{c}-0.0499 * * * * \\
(-9.3697)\end{array}$ \\
\hline Operating Margin & $\begin{array}{c}-0.9655^{* * *} * \\
(-3.5465)\end{array}$ & $\begin{array}{c}-1.0154 * * * \\
(-3.6995)\end{array}$ & $\begin{array}{c}-0.9770 * * * \\
(-3.5729)\end{array}$ & $\begin{array}{c}-0.9615 * * * \\
(-3.5287)\end{array}$ \\
\hline Observations & 6,122 & 6,122 & 6,122 & 6,122 \\
\hline Industry FE & Yes & Yes & Yes & Yes \\
\hline Year FE & Yes & Yes & Yes & Yes \\
\hline Pseudo R-squared & 0.158 & 0.158 & 0.159 & 0.156 \\
\hline
\end{tabular}


Panel B: Sub-sample regressions of ratings on centralities by zones of default probabilities

\begin{tabular}{|c|c|c|c|c|c|c|c|c|c|c|c|c|}
\hline & \multicolumn{4}{|c|}{ Low Default Probability } & \multicolumn{4}{|c|}{ Medium Default Probability } & \multicolumn{4}{|c|}{ High Default Probability } \\
\hline & $(1)$ & $(2)$ & (3) & (4) & $(5)$ & (6) & (7) & (8) & (9) & (10) & (11) & (12) \\
\hline Variables & Rating & Rating & Rating & Rating & Rating & Rating & Rating & Rating & Rating & Rating & Rating & Rating \\
\hline Between & $\begin{array}{c}-0.1393 * * * \\
(-3.2285)\end{array}$ & & & & $\begin{array}{c}-0.1617 * * * \\
(-4.3781)\end{array}$ & & & & $\begin{array}{c}-0.0573 \\
(-1.1890)\end{array}$ & & & \\
\hline Closeness & & $\begin{array}{c}-0.0708 \\
(-1.4494)\end{array}$ & & & & $\begin{array}{c}-0.1450^{* * *} \\
(-2.8169)\end{array}$ & & & & $\begin{array}{c}-0.1394 * * \\
(-2.1945)\end{array}$ & & \\
\hline Degree & & & $\begin{array}{c}-0.1631^{* * *} \\
(-2.9271)\end{array}$ & & & & $\begin{array}{c}-0.1863^{* * *} \\
(-4.2966)\end{array}$ & & & & $\begin{array}{c}-0.1236^{* * *} \\
(-2.8259)\end{array}$ & \\
\hline Eigen & & & & $\begin{array}{c}-0.0215 \\
(-0.4541)\end{array}$ & & & & $\begin{array}{c}-0.0634 \\
(-1.2448)\end{array}$ & & & & $\begin{array}{c}-0.0219 \\
(-0.6369)\end{array}$ \\
\hline Size & $\begin{array}{c}-0.5564 * * * \\
(-11.7630)\end{array}$ & $\begin{array}{c}-0.5784^{* * *} \\
(-11.8383)\end{array}$ & $\begin{array}{c}-0.5516^{* * *} \\
(-11.4786)\end{array}$ & $\begin{array}{c}-0.6004 * * * \\
(-13.0841)\end{array}$ & $\begin{array}{c}-0.4983^{* * *} \\
(-9.2923)\end{array}$ & $\begin{array}{c}-0.5024 * * * \\
(-9.7314)\end{array}$ & $\begin{array}{c}-0.4862 * * * \\
(-9.0459)\end{array}$ & $\begin{array}{l}-0.5472 * * * \\
(-10.7022)\end{array}$ & $\begin{array}{c}-0.6071^{* * *} \\
(-10.3960)\end{array}$ & $\begin{array}{c}-0.5795^{* * *} \\
(-9.7164)\end{array}$ & $\begin{array}{c}-0.5775^{* * * *} \\
(-9.9181)\end{array}$ & $\begin{array}{c}-0.6266^{* * *} \\
(-11.5924)\end{array}$ \\
\hline Leverage & $\begin{array}{c}1.9479 * * * \\
(7.3436)\end{array}$ & $\begin{array}{c}1.9298 * * * \\
(7.2469)\end{array}$ & $\begin{array}{c}1.9816^{* * *} \\
(7.4166)\end{array}$ & $\begin{array}{c}1.9208^{* * *} \\
(7.1908)\end{array}$ & $\begin{array}{c}0.2905 \\
(0.9166)\end{array}$ & $\begin{array}{c}0.3433 \\
(1.1028)\end{array}$ & $\begin{array}{c}0.3790 \\
(1.2000)\end{array}$ & $\begin{array}{c}0.2635 \\
(0.8323)\end{array}$ & $\begin{array}{c}-0.3196 \\
(-0.9023)\end{array}$ & $\begin{array}{c}-0.3338 \\
(-0.9564)\end{array}$ & $\begin{array}{c}-0.3247 \\
(-0.9229)\end{array}$ & $\begin{array}{c}-0.3066 \\
(-0.8651)\end{array}$ \\
\hline Interest Coverage & $\begin{array}{c}-0.0367 * * * \\
(-5.4169)\end{array}$ & $\begin{array}{c}-0.0364 * * * \\
(-5.3482)\end{array}$ & $\begin{array}{c}-0.0355 * * * \\
(-5.2334)\end{array}$ & $\begin{array}{c}-0.0369 * * * \\
(-5.3973)\end{array}$ & $\begin{array}{c}-0.0271 * * * \\
(-4.4257)\end{array}$ & $\begin{array}{c}-0.0262^{* * *} \\
(-4.2091)\end{array}$ & $\begin{array}{c}-0.0254 * * * \\
(-4.1249)\end{array}$ & $\begin{array}{c}-0.0276^{* * *} \\
(-4.3931)\end{array}$ & $\begin{array}{c}-0.0472 * * * \\
(-7.3963)\end{array}$ & $\begin{array}{c}-0.0459^{* * *} \\
(-7.0402)\end{array}$ & $\begin{array}{c}-0.0455^{* * * *} \\
(-7.0643)\end{array}$ & $\begin{array}{c}-0.0474 * * * \\
(-7.3493)\end{array}$ \\
\hline Operating Margin & $\begin{array}{l}-0.7499 * \\
(-1.8599)\end{array}$ & $\begin{array}{l}-0.7686^{*} \\
(-1.8706)\end{array}$ & $\begin{array}{l}-0.7965^{*} \\
(-1.9577)\end{array}$ & $\begin{array}{l}-0.7338^{*} \\
(-1.7967)\end{array}$ & $\begin{array}{c}-0.4123 \\
(-1.0871)\end{array}$ & $\begin{array}{c}-0.4726 \\
(-1.2264)\end{array}$ & $\begin{array}{c}-0.4018 \\
(-1.0556)\end{array}$ & $\begin{array}{c}-0.4835 \\
(-1.2586)\end{array}$ & $\begin{array}{c}-0.4498 \\
(-1.2319)\end{array}$ & $\begin{array}{c}-0.5276 \\
(-1.4359)\end{array}$ & $\begin{array}{c}-0.4751 \\
(-1.2938)\end{array}$ & $\begin{array}{c}-0.4427 \\
(-1.2181)\end{array}$ \\
\hline Observations & 1,909 & 1,909 & 1,909 & 1,909 & 2,190 & 2,190 & 2,190 & 2,190 & 2,023 & 2,023 & 2,023 & 2,023 \\
\hline Industry FE & Yes & Yes & Yes & Yes & Yes & Yes & Yes & Yes & Yes & Yes & Yes & Yes \\
\hline Year FE & Yes & Yes & Yes & Yes & Yes & Yes & Yes & Yes & Yes & Yes & Yes & Yes \\
\hline Pseudo R-squared & 0.155 & 0.152 & 0.155 & 0.152 & 0.143 & 0.141 & 0.143 & 0.139 & 0.133 & 0.134 & 0.135 & 0.132 \\
\hline
\end{tabular}


Panel C: Regressions of ratings on probability of default - distress zone vs. safe zone

\begin{tabular}{|c|c|c|c|c|}
\hline & $(1)$ & (2) & (3) & (4) \\
\hline Variables & Rating & Rating & Rating & Rating \\
\hline DefaultProbDum & $\begin{array}{c}0.6707 * * * \\
(-9.9447)\end{array}$ & $\begin{array}{c}0.6486 * * * \\
(-9.5757)\end{array}$ & $\begin{array}{c}0.6522 * * * \\
(-9.6094)\end{array}$ & $\begin{array}{c}0.6622 * * * \\
(-9.7967)\end{array}$ \\
\hline Between & $\begin{array}{c}-0.1432 * * * \\
(-4.6802)\end{array}$ & & & \\
\hline Between *DefaultProbDum & $\begin{array}{c}0.0670 \\
(1.4433)\end{array}$ & & & \\
\hline Closeness & & $\begin{array}{c}-0.0416 \\
(-1.4151)\end{array}$ & & \\
\hline Closeness $*$ DefaultProbDum & & $\begin{array}{l}-0.0949^{*} \\
(-1.8207)\end{array}$ & & \\
\hline Degree & & & $\begin{array}{c}-0.1042 * * * \\
(-3.3270)\end{array}$ & \\
\hline Degree * DefaultProbDum & & & $\begin{array}{c}-0.0201 \\
(-0.4322)\end{array}$ & \\
\hline Eigen & & & & $\begin{array}{c}-0.0160 \\
(-0.7975)\end{array}$ \\
\hline Eigen * DefaultProbDum & & & & $\begin{array}{c}-0.0278 \\
(-0.8187)\end{array}$ \\
\hline Size & $\begin{array}{c}-0.5998 * * * \\
(-21.2744)\end{array}$ & $\begin{array}{r}-0.6126 * * * \\
(-22.2194)\end{array}$ & $\begin{array}{c}-0.6002 * * * \\
(-21.6222)\end{array}$ & $\begin{array}{c}-0.6311 * * * \\
(-23.3555)\end{array}$ \\
\hline Leverage & $\begin{array}{c}1.2356^{* * * *} \\
(8.6774)\end{array}$ & $\begin{array}{c}1.2316^{* * * *} \\
(8.6709)\end{array}$ & $\begin{array}{c}1.2395 * * * \\
(8.7023)\end{array}$ & $\begin{array}{c}1.2187 * * * \\
(8.5581)\end{array}$ \\
\hline Interest Coverage & $\begin{array}{c}-0.0512 * * * \\
(-12.7815)\end{array}$ & $\begin{array}{r}-0.0505 * * * \\
(-12.4928)\end{array}$ & $\begin{array}{r}-0.0504 * * * \\
(-12.5395)\end{array}$ & $\begin{array}{c}-0.0515 * * * \\
(-12.8250)\end{array}$ \\
\hline Operating Margin & $\begin{array}{c}-0.9565 * * * \\
(-4.9054)\end{array}$ & $\begin{array}{c}-0.9519 * * * \\
(-4.8136)\end{array}$ & $\begin{array}{c}-0.9610 * * * \\
(-4.9084)\end{array}$ & $\begin{array}{c}-0.9134 * * * \\
(-4.6734)\end{array}$ \\
\hline Observations & 8,982 & 8,982 & 8,982 & 8,982 \\
\hline Industry FE & Yes & Yes & Yes & Yes \\
\hline Year FE & Yes & Yes & Yes & Yes \\
\hline Pseudo R-squared & 0.193 & 0.192 & 0.193 & 0.192 \\
\hline
\end{tabular}

Coefficients significant at the $1 \%, 5 \%$, and $10 \%$ are marked by $* * *, * *, *$ respectively. 
Table 6

Ratings and board connectivity during recessions -

This table presents the combined effect of recessions and standardized centralities on Ratings.

Variables are defined in Appendix 2. We interact the recession indicator variable with centralities. Industry fixed effects with firm-level clustered standard errors are employed. Control variables are winsorized at the 5\% level and then standardized. t-statistics in parenthesis.

\begin{tabular}{|c|c|c|c|c|}
\hline & (1) & (2) & (3) & (4) \\
\hline Variables & Rating & Rating & Rating & Rating \\
\hline Recession & $\begin{array}{c}0.0015 \\
(0.1053)\end{array}$ & $\begin{array}{c}0.0100 \\
(0.7006)\end{array}$ & $\begin{array}{c}0.0017 \\
(0.1212)\end{array}$ & $\begin{array}{c}0.0057 \\
(0.4000)\end{array}$ \\
\hline Between & $\begin{array}{c}-0.1620 * * * \\
(-4.1696)\end{array}$ & & & \\
\hline Recbetw & $\begin{array}{c}-0.0505^{* * *} \\
(-3.1261)\end{array}$ & & & \\
\hline Closeness & & $\begin{array}{c}0.0191 \\
(0.7866)\end{array}$ & & \\
\hline Recclos & & $\begin{array}{c}-0.0291 * * \\
(-2.0260)\end{array}$ & & \\
\hline Degree & & & $\begin{array}{c}-0.1473 * * * \\
(-5.9538)\end{array}$ & \\
\hline Recdegr & & & $\begin{array}{c}-0.0466 * * * \\
(-3.0597)\end{array}$ & \\
\hline Eigen & & & & $\begin{array}{c}-0.0404 * * \\
(-2.2099)\end{array}$ \\
\hline Receige & & & & $\begin{array}{l}-0.0127 \\
(-0.5822)\end{array}$ \\
\hline Size & $\begin{array}{c}-0.7376 * * * \\
(-20.4637)\end{array}$ & $\begin{array}{c}-0.8102^{* * *} \\
(-23.0561)\end{array}$ & $\begin{array}{c}-0.7356 * * * \\
(-21.2553)\end{array}$ & $\begin{array}{c}-0.7962 * * * \\
(-23.6530)\end{array}$ \\
\hline Leverage & $\begin{array}{c}0.2220^{* * *} \\
(8.7614)\end{array}$ & $\begin{array}{c}0.2159^{* * *} \\
(8.5280)\end{array}$ & $\begin{array}{c}0.2241 * * * \\
(8.8865)\end{array}$ & $\begin{array}{c}0.2160 * * * \\
(8.5423)\end{array}$ \\
\hline Interest Coverage & $\begin{array}{c}-0.3237 * * * \\
(-11.6937)\end{array}$ & $\begin{array}{c}-0.3328 * * * \\
(-11.7485)\end{array}$ & $\begin{array}{c}-0.3158 * * * \\
(-11.4049)\end{array}$ & $\begin{array}{c}-0.3273 * * * \\
(-11.7053)\end{array}$ \\
\hline Operating Margin & $\begin{array}{c}-0.1329 * * * \\
(-5.4297)\end{array}$ & $\begin{array}{c}-0.1268^{* * *} \\
(-5.1402)\end{array}$ & $\begin{array}{c}-0.1357 * * * \\
(-5.5543)\end{array}$ & $\begin{array}{c}-0.1293 * * * \\
(-5.2746)\end{array}$ \\
\hline Observations & 11,172 & 11,172 & 11,172 & 11,172 \\
\hline Industry FE & Yes & Yes & Yes & Yes \\
\hline Pseudo R-squared & 0.154 & 0.150 & 0.153 & 0.150 \\
\hline
\end{tabular}

Coefficients significant at the $1 \%, 5 \%$, and $10 \%$ are marked by $* * *, * *, *$ respectively. 
Table 7

Ratings, board connectivity, just below investment grade (BB), and just-above investment grade (BBB)

This table replicates the regression results in Table 4 for firms that have a credit rating of $\mathrm{BBB}+$, $\mathrm{BBB}$, and BBB- (just above investment grade), and BB+, BB, and BB- (just below investment grade). The dependent variable is Ratings. Variables are defined in Appendix 2. Two-way fixed effects with industry and year are employed with firm-level clustered standard errors.

Centralities are standardized. Control variables are winsorized at the 5\% level and then standardized. $\mathrm{t}$-statistics in parenthesis.

\begin{tabular}{|c|c|c|c|c|c|c|c|c|}
\hline & \multicolumn{4}{|c|}{ Just - Above investment grade } & \multicolumn{4}{|c|}{ Just - Below Investment Grade } \\
\hline & (1) & (2) & (3) & (4) & (5) & (6) & (7) & (8) \\
\hline Variables & Rating & Rating & Rating & Rating & Rating & Rating & Rating & Rating \\
\hline \multirow[t]{2}{*}{ Between } & $-0.1084 * * *$ & & & & -0.1186 & & & \\
\hline & $(-2.9818)$ & & & & $(-1.4387)$ & & & \\
\hline \multirow[t]{2}{*}{ Closeness } & & $-0.1488 * * *$ & & & & -0.0431 & & \\
\hline & & $(-2.9612)$ & & & & $(-0.8984)$ & & \\
\hline \multirow[t]{2}{*}{ Degree } & & & $-0.1343 * * *$ & & & & -0.0778 & \\
\hline & & & $(-3.0057)$ & & & & $(-1.3333)$ & \\
\hline \multirow[t]{2}{*}{ Eigen } & & & & -0.0037 & & & & -0.0346 \\
\hline & & & & $(-0.1000)$ & & & & $(-0.9569)$ \\
\hline \multirow[t]{2}{*}{ Size } & $-0.2972 * * *$ & $-0.2794 * * *$ & $-0.2862 * * *$ & $-0.3405^{* * *}$ & $-0.6598 * * *$ & $-0.6741 * * *$ & $-0.6686^{* * *}$ & $-0.6857 * * *$ \\
\hline & $(-5.1232)$ & $(-4.7722)$ & $(-4.8636)$ & $(-6.0069)$ & $(-10.4871)$ & $(-10.5434)$ & $(-10.6069)$ & $(-11.1121)$ \\
\hline \multirow[t]{2}{*}{ Leverage } & 0.0166 & 0.0138 & 0.0185 & 0.0188 & $0.2064 * * *$ & $0.2060 * * *$ & $0.2069 * * *$ & $0.2022 * * *$ \\
\hline & $(0.2971)$ & $(0.2487)$ & (0.3309) & $(0.3349)$ & (4.1274) & (4.1307) & (4.1507) & (4.0315) \\
\hline \multirow[t]{2}{*}{ Interest Coverage } & $-0.1181 * * *$ & $-0.1102 * * *$ & $-0.1138 * * *$ & $-0.1173 * * *$ & $-0.1444 * * *$ & $-0.1446 * * *$ & $-0.1438 * * *$ & $-0.1483 * * *$ \\
\hline & $(-2.7389)$ & $(-2.5842)$ & $(-2.6499)$ & $(-2.7179)$ & $(-2.7720)$ & $(-2.7722)$ & $(-2.7523)$ & $(-2.8399)$ \\
\hline \multirow[t]{2}{*}{ Operating Margin } & $-0.1140 * * *$ & $-0.1268 * * *$ & $-0.1206^{* * *}$ & $-0.1069 * *$ & -0.0101 & -0.0092 & -0.0095 & -0.0050 \\
\hline & $(-2.6536)$ & $(-2.9493)$ & $(-2.7745)$ & $(-2.4920)$ & $(-0.2051)$ & $(-0.1865)$ & $(-0.1936)$ & $(-0.1024)$ \\
\hline Observations & 3,558 & 3,558 & 3,558 & 3,558 & 2,850 & 2,850 & 2,850 & 2,850 \\
\hline Industry FE & Yes & Yes & Yes & Yes & Yes & Yes & Yes & Yes \\
\hline Year FE & Yes & Yes & Yes & Yes & Yes & Yes & Yes & Yes \\
\hline Pseudo R-squared & 0.0488 & 0.0495 & 0.0494 & 0.0450 & 0.0956 & 0.0946 & 0.0951 & 0.0946 \\
\hline
\end{tabular}

Coefficients significant at the $1 \%, 5 \%$, and $10 \%$ are marked by $* * *, * *, *$ respectively. 
Table 8

\section{Forward-looking ratings if below investment grade}

Panel A presents the current period rating (Rating), one-year (F1 Rating) and two-year (F2 Rating) forward looking ratings for firms that were below investment grade. Panel B presents the current period rating (Rating), one-year (F1 Rating) and two-year (F2 Rating) forward looking ratings for firms that were below investment grade but migrated to investment grade. Panel C (panel D), presents the results in panel A (panel B) using a regression model. The dependent variable is Ratings. Variables are defined in Appendix 2. Twoway fixed effects with industry and year are employed with firm-level clustered standard errors. Centralities are standardized. Control variables are winsorized at the 5\% level and then standardized. t-statistics in parenthesis.

Panel A: Average of current year rating, one-year, and two-year forward-looking ratings for firms just below investment grade in the previous year

\begin{tabular}{rrrrrrrrrrrrr}
\hline & \multicolumn{3}{c}{ Between } & \multicolumn{3}{c}{ Closeness } & \multicolumn{3}{c}{ Degree } \\
\hline Quartiles & Rating & F1 Rating & F2 Rating & Rating & F1 Rating & F2 Rating & Rating & F1 Rating & F2 Rating & Rating & F1 Rating & F2 Rating \\
\hline 1 & 12.6768 & 12.6027 & 12.5000 & 12.7778 & 12.9366 & 12.9683 & 12.5828 & 12.7798 & 12.8936 & 12.7857 & 12.9484 & 12.9407 \\
2 & 12.9559 & 12.8721 & 12.8044 & 12.9269 & 12.8627 & 12.7566 & 13.0080 & 12.9126 & 12.8127 & 12.9012 & 12.8408 & 12.7495 \\
3 & 12.6392 & 12.5041 & 12.3503 & 12.6689 & 12.5193 & 12.3883 & 12.5998 & 12.4612 & 12.3270 & 12.6499 & 12.4902 & 12.3577 \\
4 & 11.7332 & 11.6265 & 11.4253 & 11.8339 & 11.7302 & 11.5156 & 11.8911 & 11.7854 & 11.5627 & 11.7940 & 11.6843 & 11.4412 \\
\hline
\end{tabular}

Panel B: Average of current year rating, one-year, and two-year forward-looking ratings for firms just below investment grade in the previous year that migrated into investment grade

\begin{tabular}{rrrrrrrrrrrrr}
\hline \multicolumn{1}{c}{ Quartiles } & Rating & F1 Rating & F2 Rating & Rating & F1 Rating & F2 Rating & Rating & F1 Rating & F2 Rating & Rating & F1 Rating & F2 Rating \\
\hline 1 & 6.4286 & 6.4286 & 6.5714 & 8.4615 & 8.6923 & 8.8333 & 7.1429 & 7.1429 & 7.3333 & 8.4286 & 8.6429 & 8.7692 \\
2 & 8.4295 & 8.3526 & 8.5946 & 8.2077 & 8.1846 & 8.3760 & 8.4088 & 8.3942 & 8.6250 & 8.2245 & 8.1769 & 8.3786 \\
3 & 8.2429 & 8.1286 & 8.3196 & 8.3310 & 8.2075 & 8.4322 & 8.2769 & 8.1648 & 8.3589 & 8.3515 & 8.2313 & 8.4119 \\
4 & 7.3623 & 7.3949 & 7.4571 & 7.3275 & 7.3345 & 7.3962 & 7.3201 & 7.3201 & 7.3920 & 7.1751 & 7.1984 & 7.3103 \\
\hline
\end{tabular}


Panel C: Regressions of current year rating, one-year and two-year forward-looking ratings for firms below investment grade in the previous year

\begin{tabular}{|c|c|c|c|c|c|c|c|c|c|c|c|c|}
\hline & $(1)$ & (2) & (3) & (4) & $(5)$ & (6) & (7) & (8) & (9) & $(10)$ & $(11)$ & $(12)$ \\
\hline Variables & Rating & Rating & Rating & Rating & F1 Rating & F1 Rating & F1 Rating & F1 Rating & F2 Rating & F2 Rating & F2 Rating & F2 Rating \\
\hline \multirow[t]{2}{*}{ Between } & $-0.0877 * * *$ & & & & $-0.1107 * * *$ & & & & $-0.1238 * * *$ & & & \\
\hline & $(-2.5955)$ & & & & $(-3.0746)$ & & & & $(-3.2279)$ & & & \\
\hline \multirow[t]{2}{*}{ Closeness } & & 0.0172 & & & & 0.0148 & & & & -0.0122 & & \\
\hline & & $(0.6724)$ & & & & $(0.5034)$ & & & & $(-0.3883)$ & & \\
\hline \multirow[t]{2}{*}{ Degree } & & & -0.0345 & & & & -0.0455 & & & & $-0.0673 * *$ & \\
\hline & & & $(-1.1669)$ & & & & $(-1.3999)$ & & & & $(-1.9713)$ & \\
\hline \multirow[t]{2}{*}{ Eigen } & & & & -0.0069 & & & & -0.0060 & & & & -0.0163 \\
\hline & & & & $(-0.3525)$ & & & & $(-0.2704)$ & & & & $(-0.7198)$ \\
\hline \multirow[t]{2}{*}{ Size } & $-0.7248 * * *$ & $-0.7549 * * *$ & $-0.7384 * * *$ & $-0.7477 * * *$ & $-0.7199 * * *$ & $-0.7570 * * *$ & $-0.7375 * * *$ & $-0.7505^{* * *}$ & $-0.6473 * * *$ & $-0.6797 * * *$ & $-0.6632 * * *$ & $-0.6823 * * *$ \\
\hline & $(-17.4338)$ & $(-17.9963)$ & $(-17.7931)$ & $(-18.4310)$ & $(-15.3977)$ & $(-15.9406)$ & $(-15.8115)$ & $(-16.5685)$ & $(-13.2130)$ & $(-13.7458)$ & $(-13.6033)$ & $(-14.5350)$ \\
\hline \multirow[t]{2}{*}{ Leverage } & $0.2814 * * *$ & $0.2787 * * *$ & $0.2810 * * *$ & $0.2796 * * *$ & $0.3098 * * *$ & $0.3065^{* * *}$ & $0.3092 * * *$ & $0.3073 * * *$ & $0.2568 * * *$ & $0.2540 * * *$ & $0.2567 * * *$ & $0.2533 * * *$ \\
\hline & $(11.8531)$ & $(11.7743)$ & $(11.8496)$ & $(11.7779)$ & $(11.3286)$ & $(11.2201)$ & (11.3159) & $(11.2362)$ & $(8.8498)$ & $(8.7662)$ & $(8.8542)$ & $(8.7248)$ \\
\hline \multirow[t]{2}{*}{ Interest Coverage } & $-0.3262 * * *$ & $-0.3343 * * *$ & $-0.3290 * * *$ & $-0.3320 * * *$ & $-0.4448 * * *$ & $-0.4550 * * *$ & $-0.4485 * * *$ & $-0.4528 * * *$ & $-0.5214 * * *$ & $-0.5297 * * *$ & $-0.5241 * * *$ & $-0.5294 * * *$ \\
\hline & $(-9.7026)$ & $(-9.9772)$ & $(-9.8017)$ & $(-9.8924)$ & $(-10.5039)$ & $(-10.7773)$ & $(-10.6236)$ & $(-10.7138)$ & $(-10.8427)$ & $(-11.0235)$ & $(-10.9159)$ & $(-11.0108)$ \\
\hline \multirow[t]{2}{*}{ Operating Margin } & $-0.1511 * * *$ & $-0.1455 * * *$ & $-0.1493 * * *$ & $-0.1473 * * *$ & $-0.2033 * * *$ & $-0.1971 * * *$ & $-0.2010 * * *$ & $-0.1985 * * *$ & $-0.2348 * * *$ & $-0.2309 * * *$ & $-0.2338 * * *$ & $-0.2305 * * *$ \\
\hline & $(-5.2978)$ & $(-5.0841)$ & $(-5.2344)$ & $(-5.1580)$ & $(-6.1510)$ & $(-5.9426)$ & $(-6.0863)$ & $(-6.0041)$ & $(-6.5192)$ & $(-6.3766)$ & $(-6.4947)$ & $(-6.3808)$ \\
\hline Observations & 5,936 & 5,936 & 5,936 & 5,936 & 4,808 & 4,808 & 4,808 & 4,808 & 4,001 & 4,001 & 4,001 & 4,001 \\
\hline Industry FE & Yes & Yes & Yes & Yes & Yes & Yes & Yes & Yes & Yes & Yes & Yes & Yes \\
\hline Year FE & Yes & Yes & Yes & Yes & Yes & Yes & Yes & Yes & Yes & Yes & Yes & Yes \\
\hline Pseudo R-squared & 0.163 & 0.162 & 0.163 & 0.162 & 0.176 & 0.175 & 0.176 & 0.175 & 0.170 & 0.168 & 0.169 & 0.168 \\
\hline
\end{tabular}


Panel D: Regressions of current year rating, one-year and two-year forward-looking ratings for firms just below investment grade that migrated into investment grade

\begin{tabular}{|c|c|c|c|c|c|c|c|c|c|c|c|c|}
\hline & $(1)$ & (2) & (3) & (4) & (5) & (6) & (7) & $(8)$ & (9) & $(10)$ & (11) & (12) \\
\hline Variables & Rating & Rating & Rating & Rating & F1 Rating & F1 Rating & F1 Rating & F1 Rating & F2 Rating & F2 Rating & F2 Rating & F2 Rating \\
\hline \multirow[t]{2}{*}{ Between } & $-0.1446 * * *$ & & & & $-0.1532 * * *$ & & & & $-0.1459 * * *$ & & & \\
\hline & $(-4.4683)$ & & & & $(-4.3757)$ & & & & $(-3.5065)$ & & & \\
\hline \multirow[t]{2}{*}{ Closeness } & & $-0.0982 * *$ & & & & $-0.1133 * *$ & & & & $-0.1361 * * *$ & & \\
\hline & & $(-2.3176)$ & & & & $(-2.4565)$ & & & & $(-2.7298)$ & & \\
\hline \multirow[t]{2}{*}{ Degree } & & & $-0.1510 * * *$ & & & & $-0.1402 * * *$ & & & & $-0.1517 * * *$ & \\
\hline & & & $(-4.2928)$ & & & & $(-3.6447)$ & & & & $(-3.6980)$ & \\
\hline \multirow[t]{2}{*}{ Eigen } & & & & $-0.0601 * *$ & & & & $-0.0505^{*}$ & & & & $-0.0597 *$ \\
\hline & & & & $(-2.1027)$ & & & & $(-1.7180)$ & & & & $(-1.8812)$ \\
\hline \multirow[t]{2}{*}{ Size } & $-0.4862 * * *$ & $-0.5089 * * *$ & $-0.4848 * * *$ & $-0.5393 * * *$ & $-0.5305 * * *$ & $-0.5503 * * *$ & $-0.5369 * * *$ & $-0.5912 * * *$ & $-0.4804 * * *$ & $-0.4846^{* * *}$ & $-0.4769 * * *$ & $-0.5346^{* * *}$ \\
\hline & $(-8.4046)$ & $(-8.8883)$ & $(-8.4795)$ & $(-9.7821)$ & $(-8.6712)$ & $(-8.9774)$ & $(-8.8159)$ & $(-10.0880)$ & $(-7.4199)$ & $(-7.4028)$ & $(-7.4004)$ & $(-8.5588)$ \\
\hline \multirow[t]{2}{*}{ Leverage } & $0.1196 * *$ & $0.1214 * *$ & $0.1163 * *$ & $0.1167 * *$ & $0.1184^{* *}$ & $0.1192 * *$ & $0.1149 * *$ & $0.1155^{* *}$ & $0.1165^{* *}$ & $0.1148 * *$ & $0.1112 *$ & $0.1087^{*}$ \\
\hline & $(2.3854)$ & $(2.4219)$ & $(2.3250)$ & $(2.2959)$ & $(2.2464)$ & $(2.2401)$ & $(2.1657)$ & $(2.1409)$ & $(2.0466)$ & $(2.0010)$ & (1.9407) & $(1.8660)$ \\
\hline \multirow[t]{2}{*}{ Interest Coverage } & $-0.3296 * * *$ & $-0.3362 * * *$ & $-0.3252 * * *$ & $-0.3369 * * *$ & $-0.4122 * * *$ & $-0.4180 * * *$ & $-0.4098 * * *$ & $-0.4227 * * *$ & $-0.4122 * * *$ & $-0.4170^{* * *}$ & $-0.4083 * * *$ & $-0.4224 * * *$ \\
\hline & $(-6.9606)$ & $(-7.0407)$ & $(-6.8536)$ & $(-6.9680)$ & $(-9.0034)$ & $(-9.0386)$ & $(-8.8804)$ & $(-9.0659)$ & $(-7.9940)$ & $(-8.0248)$ & $(-7.8624)$ & $(-8.0355)$ \\
\hline \multirow[t]{2}{*}{ Operating Margin } & $-0.1803 * * *$ & $-0.1815^{* * *}$ & $-0.1838^{* * *}$ & $-0.1751 * * *$ & $-0.2219 * * *$ & $-0.2246 * * *$ & $-0.2242 * * *$ & $-0.2166^{* * *}$ & $-0.2728 * * *$ & $-0.2833 * * *$ & $-0.2807 * * *$ & $-0.2714 * * *$ \\
\hline & $(-4.1973)$ & $(-4.2563)$ & $(-4.2801)$ & $(-4.0874)$ & $(-5.0599)$ & $(-5.1105)$ & $(-5.0849)$ & $(-4.9394)$ & $(-5.5034)$ & $(-5.6955)$ & $(-5.6283)$ & $(-5.4316)$ \\
\hline Observations & 859 & 859 & 859 & 859 & 859 & 859 & 859 & 859 & 788 & 788 & 788 & 788 \\
\hline Industry FE & Yes & Yes & Yes & Yes & Yes & Yes & Yes & Yes & Yes & Yes & Yes & Yes \\
\hline Year FE & Yes & Yes & Yes & Yes & Yes & Yes & Yes & Yes & Yes & Yes & Yes & Yes \\
\hline Pseudo R-squared & 0.138 & 0.135 & 0.138 & 0.134 & 0.159 & 0.155 & 0.157 & 0.153 & 0.153 & 0.151 & 0.153 & 0.149 \\
\hline
\end{tabular}

Coefficients significant at the $1 \%, 5 \%$, and $10 \%$ are marked by $* * *, * *, *$ respectively. 
Table 9

\section{Ratings and board connectivity - endogeneity -}

This table presents the regression results of ratings against lagged centralities and the second stage regression of the instrumental variables regression. Variables are defined in Appendix 2. The dependent variable is Ratings. Two-way fixed effects with industry and year are employed with firm-level clustered standard errors. Centralities are standardized. Control variables are winsorized at the 5\% level and then standardized. t-statistics in parenthesis.

\begin{tabular}{|c|c|c|c|c|c|c|c|c|}
\hline & \multicolumn{4}{|c|}{ Lagged centralities } & \multicolumn{4}{|c|}{ Second-stage instrumental variable regression } \\
\hline & (1) & (2) & (3) & (4) & (5) & (6) & (7) & (8) \\
\hline Variables & Rating & Rating & Rating & Rating & Rating & Rating & Rating & Rating \\
\hline \multirow[t]{2}{*}{ Between } & $-0.1183 * * *$ & & & & $-1.6936 * * *$ & & & \\
\hline & $(-3.9361)$ & & & & $(-2.8982)$ & & & \\
\hline \multirow[t]{2}{*}{ Closeness } & & $-0.0784 * * *$ & & & & 0.0722 & & \\
\hline & & $(-2.7132)$ & & & & $(0.1664)$ & & \\
\hline \multirow[t]{2}{*}{ Degree } & & & $-0.1338 * * *$ & & & & -0.6517 & \\
\hline & & & $(-4.8900)$ & & & & $(-1.5698)$ & \\
\hline \multirow[t]{2}{*}{ Eigen } & & & & $-0.0404 * *$ & & & & $-1.4760 * *$ \\
\hline & & & & $(-2.1281)$ & & & & $(-2.3004)$ \\
\hline \multirow[t]{2}{*}{ Size } & $-0.8490 * * *$ & $-0.8633 * * *$ & $-0.8386^{* * *}$ & $-0.8932 * * *$ & $-1.1906 * * *$ & $-1.9986 * * *$ & $-1.6455^{* * *}$ & $-1.6802 * * *$ \\
\hline & $(-20.5423)$ & $(-21.3659)$ & $(-20.6170)$ & $(-22.7016)$ & $(-4.4380)$ & $(-9.4767)$ & $(-8.0377)$ & $(-13.2488)$ \\
\hline \multirow[t]{2}{*}{ Leverage } & $0.2494 * * *$ & $0.2502 * * *$ & $0.2534 * * *$ & $0.2454 * * *$ & $0.5226 * * *$ & $0.4675^{* * *}$ & $0.5052 * * *$ & $0.4659 * * *$ \\
\hline & $(8.5348)$ & $(8.5916)$ & (8.6982) & $(8.3844)$ & $(16.1655)$ & (13.7672) & (15.5186) & (16.5771) \\
\hline \multirow[t]{2}{*}{ Interest Coverage } & $-0.3741 * * *$ & $-0.3733 * * *$ & $-0.3675 * * *$ & $-0.3780 * * *$ & $-0.7165 * * *$ & $-0.8829 * * *$ & $-0.7872 * * *$ & $-0.7235^{* * *}$ \\
\hline & $(-12.3680)$ & $(-12.2423)$ & $(-12.1318)$ & $(-12.4131)$ & $(-11.4610)$ & $(-15.1388)$ & $(-12.8434)$ & $(-10.0501)$ \\
\hline \multirow[t]{2}{*}{ Operating Margin } & $-0.1381 * * *$ & $-0.1426 * * *$ & $-0.1417 * * *$ & $-0.1363 * * *$ & $-0.2991 * * *$ & $-0.2596 * * *$ & $-0.2935 * * *$ & $-0.3073 * * *$ \\
\hline & $(-5.0048)$ & $(-5.1038)$ & $(-5.1236)$ & $(-4.9225)$ & $(-10.2573)$ & $(-5.5872)$ & $(-9.7732)$ & $(-9.0636)$ \\
\hline \multirow[t]{2}{*}{ Constant } & & & & & $8.9586 * * *$ & $8.2767 * * *$ & $8.3948 * * *$ & $8.2997 * * *$ \\
\hline & & & & & (32.8307) & (49.3981) & $(61.0566)$ & $(69.8351)$ \\
\hline Observations & 9,399 & 9,399 & 9,399 & 9,399 & 11,172 & 11,172 & 11,172 & 11,172 \\
\hline Industry FE & Yes & Yes & Yes & Yes & Yes & Yes & Yes & Yes \\
\hline Year FE & Yes & Yes & Yes & Yes & Yes & Yes & Yes & Yes \\
\hline Pseudo R-squared & 0.169 & 0.168 & 0.169 & 0.167 & & & & \\
\hline Adj. R-Squared & & & & & 0.4691 & 0.5913 & 0.5923 & 0.4441 \\
\hline
\end{tabular}

Coefficients significant at the $1 \%, 5 \%$, and $10 \%$ are marked by $* * *, * *, *$ respectively. 


\section{Appendix 1}

Degree Centrality - A director can be highly connected if he is a member of multiple boards that provides many relationships and conduits of information transfer resulting in value enhancing opportunities and increased trustworthiness. In simple terms, degree centrality is the total number of connections possessed by a director. Degree centrality is measured as follows. Let $A_{i j}$ denote a matrix containing a value of 1 if directors $i$ and $j$ are connected and 0 otherwise. Let $C_{D}$ (i) denote the number of nearest neighbors to director $I, C_{D}(i)=\sum_{j} A_{i j}$ and scaled degree centrality is $C_{D}^{*}(i)=\frac{1}{n-1} C_{D}(i)$, where $n$ is the number of directors in the network.

Closeness Centrality - a director can be highly connected if she maintains shorter and closer ties to other boards making information exchange faster. The concept of closeness refers to the 'number of hoops' a director has to jump before she gets to another director with important information for her firm. Let $d(i, j)$ denote the shortest number of steps that connect director $i$ to director $j$ in the network. From director $i$ 's perspective, the value $\sum_{j} d(i, j)$ denotes the total number of (shortest) steps taken to connect with all other directors in the network. The measure of 'shortest' captures closeness. The inverse of this measure is denoted by $C_{C}(i)=\frac{1}{\sum_{j} d(i, j)}$ and measures closeness centrality, where values indicate how closely tied director $i$ is to other directors in the network. The scaled measure is $C_{C}^{*}(i, j)=(n-1) C_{C}(i)$. Betweenness Centrality - a director can be highly-connected if he occupies key positions on paths between other boards, making him a key agent of information transfer. In those instances, a director attains the unique position to serve as a bridge between two distinct network groups of 
directors. In this context, a director serves as a resource that facilitates making contacts. An example of such a director would be a person from a financial institution who serves on boards of an industrial firm. The director belongs to both clusters but may not possess the specialized industrial knowledge to be closely connected with the other firms within a cluster. Let $d_{s t}(i)$ denote the number of shortest paths between directors $s$ and $t$ with director $i$ being an intermediate connection and let $d_{s t}(i)$ denote the total number of shortest links that connect directors $s$ and $t$ (including those that involve director $i$ ). Betweenness centrality for director $i$ is measured as $C_{B}(i)=\sum_{s \neq t \neq i} \frac{d_{s t}(i)}{d_{s t}}$, and the scaled measure is given as $C_{B}^{*}(i)=\frac{2}{(n-1)(n-2)} C_{B}(i)$. Eigenvector Centrality - this is derived from degree centrality, which distinguishes that more direct connections is influential when those connection directors are also influential with respect to their centralities. Further, there can be instances when a director may not be well-connected with other directors, but can have a connection with other directors who are very influential by virtue of their position in the network. Such a less than well-connected director benefits from her contacts. Let $v_{i}$ denote the importance of director $i$. The value of $v_{i}$ depends on the value of $v_{j}$ for director $j$ if director $i$ is connected to director $j$. If we consider all directors in the network, $v_{i}$ is determined by $\sum_{j} A_{i j} v_{j}$. To compute $v_{i}$, suppose we assign a value of 1 to each director's importance and recursively determine $v_{i}$, by the following relation $v_{i} \leftarrow \sum_{j} A_{i j}\left(v_{j}\right)$, the values increase in size without bound. To normalize this process, let $\lambda$ be a normalizing constant such that $v_{i}=\frac{1}{\lambda} \sum_{j} A_{i j}\left(v_{j}\right)$. In matrix notation, this is written as $\mathrm{Av}=\lambda \mathrm{v}$. The constant $\lambda$ is easily seen as an eigenvalue measure. The eigenvector associated with the largest eigenvalue indicates the measure of each director's importance in the network. 
The data to calculate these director level centralities is obtained from BoardEx. Using this database, we create the network of directors for every year. We assume that connections formed once continue to exist even when the director is no longer connected with his counterparty through employment. Hence, our network grows exponentially over the years to reach 29 million connections by the year 2011. Although our data starts in 1999 and ends in 2011, the lack of data before 1999 does not affect the centrality calculation because we realize that the graph describing the universe of connections for all directors is dynamic and keeps evolving every year as those directors acquire new connections. We calculate the centralities every year, thereby avoiding any dependencies on the formation of the initial network of connections. BoardEx provides data on US and non-US directors. We built the network graph for US and non-US directors employed by US firms. This network graph is more inclusive and exponentially larger, but it provides unbiased calculations. We sacrificed computation speed for an unbiased network. 


\section{Appendix 2 - Variable Definitions}

\begin{tabular}{|c|c|}
\hline Variable & Definition \\
\hline Assets & Total assets (in millions \$) \\
\hline Between & $\begin{array}{l}\text { The standardized value of betweenness centrality calculated } \\
\text { per Appendix } 1 .\end{array}$ \\
\hline Board Age & Average age of the board of directors \\
\hline Board Independence & Percentage of independent directors on the board \\
\hline Board Size & Total number of members on the board of directors \\
\hline Board Tenure & Average tenure of the board of directors \\
\hline Capx & Capital expenditures scaled by total sales \\
\hline Cash & Cash and equivalents scaled by total assets \\
\hline Closeness & $\begin{array}{l}\text { The standardized value of closeness centrality calculated per } \\
\text { Appendix } 1 .\end{array}$ \\
\hline Degree & $\begin{array}{l}\text { The standardized value of degree centrality calculated per } \\
\text { Appendix } 1 .\end{array}$ \\
\hline Eigen & $\begin{array}{l}\text { The standardized value of eigenvector centrality calculated } \\
\text { per Appendix } 1 .\end{array}$ \\
\hline E-Index & Entrenchment index per Bebchuk, Cohen, and Ferrell (2009) \\
\hline Interest Coverage & $\begin{array}{l}\text { Ratio of the sum of earnings before interest and tax, and } \\
\text { interest expenses to interest expenses }\end{array}$ \\
\hline Leverage & Total liabilities scaled by total assets \\
\hline Managerial Ability & $\begin{array}{l}\text { Managerial ability index per Demerjian, Lev, and McVay } \\
\text { (2012) }\end{array}$ \\
\hline Mkbk & Ratio of market value of equity to book value of equity \\
\hline Operating Margin & $\begin{array}{l}\text { Earnings before interest tax, depreciation, and amortization } \\
\text { to sales }\end{array}$ \\
\hline Rating & $\begin{array}{l}\text { Derived from the Ratings provided by COMPUSTAT. An } \\
\text { inverse coding system starting with "AAA" rating which is } \\
\text { code as } 1 \text { and a rating of "C" is coded } 21 . \text { Firms with "D," } \\
\text { "SD" rating and no rating are dropped. }\end{array}$ \\
\hline Recession & $\begin{array}{l}\text { Dummy variable that takes value of } 1 \text { for recession years per } \\
\text { National Bureau of Economic Research (NBER) }\end{array}$ \\
\hline Recbetw & The interaction of Recession and Between \\
\hline Recclos & The interaction of Recession and Closeness \\
\hline Recdegr & The interaction of Recession and Degree \\
\hline Receige & The interaction of Recession and Eigen \\
\hline Roa & $\begin{array}{l}\text { Ratio of earnings before interest tax, depreciation, and } \\
\text { amortization to total assets }\end{array}$ \\
\hline Size & Log of total assets \\
\hline Tangibility & Net property, plant and equipment scaled by total sales \\
\hline Default Probability & Distance to Default obtained from Bloomberg \\
\hline DefProbDum & $\begin{array}{l}\text { Dummy variable that takes value of } 1 \text { if a firm belongs to the } \\
\text { tertile } 3 \text { of Default Probability }\end{array}$ \\
\hline
\end{tabular}




\section{Appendix 3 - Rating Mnemonic}

\begin{tabular}{cc}
\hline Symbol Rating & Numeric Rating \\
\hline AAA & 1 \\
AA+ & 2 \\
AA & 3 \\
AA- & 4 \\
A+ & 5 \\
A & 6 \\
A- & 7 \\
BBB + & 8 \\
BBB & 9 \\
BB + & 10 \\
BB & 11 \\
BB- & 12 \\
B + & 13 \\
B & 14 \\
B- & 15 \\
CCC + & 16 \\
CCC & 17 \\
CCC- & 18 \\
CC & 19 \\
C & 20 \\
\hline
\end{tabular}

